\title{
cAMP signaling can antagonize potent glucocorticoid post-transcriptional inhibition of stanniocalcin gene expression
}

\author{
T C Groves ${ }^{1}$, G F Wagner ${ }^{2}$ and G E DiMattia ${ }^{1,3}$
}

${ }^{1}$ Department of Oncology, The University of Western Ontario and London Regional Cancer Centre, London, Ontario, Canada

${ }^{2}$ Department of Physiology, The University of Western Ontario and London Regional Cancer Centre, London, Ontario, Canada

${ }^{3}$ Department of Biochemistry, The University of Western Ontario and London Regional Cancer Centre, London, Ontario, Canada

(Requests for offprints should be addressed to G E DiMattia, London Regional Cancer Centre, 790 Commissioners Rd. E., London, Ontario, Canada, N6A 4L6; Email: dimattia@uwo.ca)

\begin{abstract}
Stanniocalcin (STC) is a glycoprotein hormone first discovered in fish as a homeostatic regulator of calcium and phosphate transport; it has recently been discovered in mammals, in which it appears to have a similar role. It has also been implicated in a number of different physiological processes through correlative studies, but the factors regulating its production have not been elucidated. In this report, we show that steady-state STC mRNA levels in the mouse corticotrope tumor line, AtT-20, were exquisitely sensitive to glucocorticoids. Hydrocortisone and dexamethasone (Dex) induced a dramatic reduction in steady-state STC mRNA levels in AtT-20 cells through a post-transcriptional mechanism. Similarly, glucocorticoids down-regulated STC mRNA levels in the human fibrosarcoma cell line, HT1080. The specificity of the
\end{abstract}

glucocorticoid-mediated decrease in STC mRNA abundance was shown using the glucocorticoid receptor antagonist, RU-486. Activation of the cAMP-signaling pathway in glucocorticoid-cultured AtT-20 cells transiently restored STC gene expression. Treatment of AtT-20 cells with the transcriptional inhibitor, actinomycin D, rescued steady-state STC mRNA levels from Dex-induced repression, indicating that the Dexmediated decrease in STC gene expression requires current gene transcription. Taken together, these results describe a unique model system in which cAMPstimulated events can reverse post-transcriptional repression of gene expression by glucocorticoids.

Journal of Endocrinology (2001) 171, 499-516

\section{Introduction}

Stanniocalcin (STC) is a secreted homodimeric glycoprotein originally discovered in bony fishes, in which it has a critical role in regulating serum $\mathrm{Ca}^{2+}$ and $\mathrm{PO}_{4}{ }^{2-}$ homeostasis (Wagner 1994). STC protects fishes from increased plasma $\mathrm{Ca}^{2+}$ concentrations through inhibition of $\mathrm{Ca}^{2+}$ uptake by the gills and gut (Wagner et al. 1986, 1988, Butkus et al. 1987, Sundell et al. 1992), and by increasing $\mathrm{PO}_{4}$ reabsorption by the kidneys $(\mathrm{Lu}$ et al. 1994). The production and secretion of STC by the corpuscles of Stannius in fish are, in turn, controlled primarily by serum $\mathrm{Ca}^{2+}$ concentrations (Wagner et al. 1989, 1991).

Mammalian STC shares approximately $73 \%$ amino acid sequence homology with fish STC, implying that its function might be highly conserved across species (Chang et al. 1995, 1996, Olsen et al. 1996, Varghese et al. 1998). Indeed, the hormone appears to regulate the movement of $\mathrm{Ca}^{2+}$ and $\mathrm{PO}_{4}$ in mammalian kidney and intestine (Wagner et al. 1997, Madsen et al. 1998). There is good evidence indicating that STC regulates mineral metabolism, but little is understood with regard to its function in tissues not associated with mineral homeostasis. Recently, numerous reports have implicated STC in different biological processes by associating an upregulation of its steady-state mRNA levels with a particular physiological state or event. An increase in STC mRNA levels was correlated with atherogenic treatment of human umbilical vein endothelial cells (Sato et al. 1998), in vitro differentiation of endothelial cells into vessels (Kahn et al. 2000), fibroblast responsiveness to serum-borne growth factors (Iyer et al. 1999), and in vitro differentiation of a neuronal cell line (Zhang et al. 1998b). Collectively, these reports indicate that STC production is sensitive to a multiplicity of biological stimuli and STC may thus contribute to the control of diverse physiological processes. However, the inter- and intracellular messengers that are responsible for increasing steady-state levels of STC mRNA described above have not been delineated.

We have shown that STC production is widespread in the adult mouse and is highly expressed in a variety of tissues throughout mouse development (Varghese et al. 1998, Stasko \& Wagner 2001). An understanding of how 
the STC gene can be regulated will be critical to our understanding of its function. With regard to hormonal regulation, only one report exists that showed that STC mRNA levels could be up-regulated in whole kidney tissue by vitamin D (Honda et al. 1999). To identify suitable cell-line models and discover factors capable of regulating STC transcription and production, we tested more than 20 different cell lines by northern analysis and found that STC was highly expressed by those of pituitary origin. In particular, the mouse corticotrope tumor line, AtT-20, produces the highest levels of STC. We have also shown that the STC gene is active in mouse pituitary and, on the basis of our cell-line survey, STC is probably expressed by all hormone-producing cell types of the intermediate and anterior lobes.

Much of our knowledge regarding the regulation of pro-opiomelanocortin (POMC), in addition to the synthesis and post-translation processing of adrenocorticotropin, has been obtained using AtT-20 cells (Bilezikjian et al. 1991, Horiba et al. 1993, Therrien \& Drouin 1993). To understand the mechanisms controlling production of STC and thereby gain insight into its potential functions, we assessed the effects of various hormonal agents and intracellular secondary messengers on STC production by AtT-20 cells. Our study provides the first direct evidence that steady-state STC mRNA levels can be dramatically down-regulated by glucocorticoids, and that activation of the cAMP-signaling pathway and inhibition of de novo gene transcription can abrogate glucocorticoid inhibition of STC mRNA levels. The widespread expression of STC in mammals, coupled with the fact that glucocorticoids are essential physiological regulators, suggests that the results presented here may reflect the regulatory role of glucocorticoids at several sites of STC production.

\section{Materials and Methods}

\section{Materials}

OptiMEM cell culture medium and fetal bovine serum (FBS) were purchased from Life Technologies (Burlington, Ontario, Canada). UltraMEM and UltraCulture media were obtained from BioWhittaker, Inc. (Walkersville, MD, USA). Actinomycin D (Act D), $\alpha-$ amanitin, 5,6,dichloro-1- $\beta$-D-ribofuranosylbenzimidazole (DRB), cycloheximide (CHX), dexamethasone (Dex), $2 \alpha$-dihydrotestosterone (DHT), 17 $\beta$-estradiol, forskolin, human/rat corticotropin releasing factor (CRF), progesterone, and the glucocorticoid receptor (GR) antagonist RU-486 were purchased from Sigma Chemical Co. (St Louis, MO, USA). Aprotinin, 8-bromo-cAMP (8Br-cAMP), leupeptin, phenylmethylsulfonyl fluoride (PMSF), and RNase A were obtained from Roche Diagonostics (Laval, Canada). Proteinase K was obtained from Life Technologies and RNase-free DNase I was purchased from Worthington Biochemical Corp.
(Freehold, NJ, USA). Stock solutions of Dex, DHT, $\beta$-estradiol, progesterone, and RU-486 were prepared in ethanol, those of Act D and forskolin were made in dimethylsulfoxide, and 8Br-cAMP, CHX and CRF were dissolved in water.

The various cDNAs used for northern analysis included: a 500 bp mouse POMC cDNA fragment in pBKSII from Dr M G Rosenfeld (University of California at San Diego, CA, USA), an 800 bp mouse STC cDNA encompassing the entire coding region, pBKSII containing $18 \mathrm{~S}$ ribosomal DNA (rDNA), and pGEM-4Z carrying a 380 bp rat cyclophilin cDNA consisting of $320 \mathrm{bp}$ of the coding region and $52 \mathrm{bp}$ of $3^{\prime}$ untranslated sequence. The $372 \mathrm{bp}$ mouse metallothionein-1 (MT-1) cDNA plasmid was obtained from Dr James Koropatnick (London Regional Cancer Centre, London, Canada). The plasmid pZL1, containing a $1.6 \mathrm{~kb}$ mouse Dexras1 cDNA was the generous gift of Dr Robert J Kemppainen (Auburn University College of Veterinary Medicine, Auburn, AL, USA).

\section{Cell culture}

The AtT-20 cell line was initially obtained from Dr M G Rosenfeld's laboratory (University of California at San Diego). The original AtT-20 cell line (CCL-89) and the adherent variant (D16 v-F2) were purchased from the ATCC (Rockville, MD, USA). Adherent AtT-20 D16 vF2 cells and HT1080 cells were passaged by trypsinization using $0.25 \%$ trypsin and $0.53 \mathrm{mM}$ EDTA and grown in OptiMEM supplemented with 10\% FBS (OptiMEM/ FBS). The CCL-89 cells grew in suspension and were passaged by dilution in OptiMEM/FBS. For studies evaluating the effects of steroids or other compounds on STC mRNA levels, cells were plated at a density of $1 \times 10^{6}$ cells (or $3 \times 10^{6}$ cells) per T-25 $\mathrm{cm}^{2}$ (or T-75 $\mathrm{cm}^{2}$ ) flask in OptiMEM/charcoal-stripped FBS or in UltraMEM supplemented with 10\% FBS (UltraMEM/FBS). After 3 days, fresh medium was added containing the following agents or combinations thereof: $10 \mu \mathrm{g} / \mathrm{ml}$ Act $\mathrm{D}, 5 \mathrm{mM}$ 8Br-cAMP, $1 \mu \mathrm{g} / \mathrm{ml} \mathrm{CHX}, 10^{-7} \mathrm{M}$ CRF, $10^{-7} \mathrm{M}$ Dex, $10^{-7} \mathrm{M}$ DHT, $10^{-7} \mathrm{M} 17 \beta$-estradiol, $10^{-5} \mathrm{M}$ forskolin, $10^{-7} \mathrm{M}$ progesterone, and $10^{-6} \mathrm{M}$ RU-486. At selected times after treatment, cells were harvested for RNA extraction by trypsinization. To assess the effect of different culture media on STC mRNA production, cells were seeded at a density of $3 \times 10^{6}$ cells per T-75 $\mathrm{cm}^{2}$ flask in OptiMEM/FBS. After 3 days, cultures were washed and the media replaced with UltraMEM/FBS. Alternatively, cells were grown in UltraMEM/FBS for 3 days, washed three times, and the media replaced with OptiMEM/FBS. In both experiments, cells were harvested at various times after the media switch, for RNA extraction. In experiments assessing the growth potential of AtT-20 cells, triplicate cultures were plated at a density of $1 \times 10^{5}$ cells per T-25 $\mathrm{cm}^{2}$ flask in either OptiMEM/FBS or UltraMEM/FBS and grown continuously for 0 to 7 days. 
At each time point, cells were harvested and counted using a hemocytometer. In addition, the growth potential of AtT-20 cells in OptiMEM/FBS was simultaneously compared with changes in STC mRNA expression. Briefly, AtT-20 cells were seeded at $3 \times 10^{5}$ cells per T-75 cm $\mathrm{cm}^{2}$ flask in OptiMEM/FBS, cultured continuously for 0 to 7 days, and then harvested for RNA isolation.

\section{RNA extraction and Northern analysis}

Total RNA was extracted using Trizol (Life Technologies) according to the manufacturer's instructions. For most experiments, $50 \mu \mathrm{g}$ total RNA was analyzed on $1 \%$ agarose containing $20 \mathrm{mM} 3$-morpholinopropanesulfonic acid, $5 \mathrm{mM}$ sodium acetate and $1 \mathrm{mM}$ EDTA, and $0.37 \mathrm{M}$ formaldehyde, transferred to Amersham Hybond-N nylon membranes (Amersham Pharmacia Biotech, Baie-d'Urfe, Quebec, Canada), and the blots baked for $2 \mathrm{~h}$ at $80^{\circ} \mathrm{C}$. Baked blots were hybridized overnight at $65{ }^{\circ} \mathrm{C}$ in $5 \mathrm{ml}$ $0.5 \mathrm{M}$ phosphate buffer $\mathrm{pH} 7 \cdot 2$, containing $7 \%(\mathrm{w} / \mathrm{v})$ SDS, and $10 \mathrm{mM}$ EDTA with $15 \times 10^{6}$ c.p.m. of the indicated probe. Radiolabelled DNA probes were prepared with $\left[\alpha{ }^{32} \mathrm{P}\right]$ deoxy-CTP $(3000 \mathrm{Ci}$, mmol; Amersham Pharmacia Biotech) using the Ready-to-Go DNA labeling beads (deoxy-CTP) from Amersham Pharmacia Biotech. Labeled DNA was separated from unincorporated radionucleotide using Sephadex G-50 columns (Amersham Pharmacia Biotech). After hybridization, blots were washed twice in $2 \times$ SSC and $0 \cdot 1 \%$ SDS for $15 \mathrm{~min}$ at room temperature, and then with $0 \cdot 1 \times \mathrm{SSC}$ and $0 \cdot 1 \%$ SDS for $30 \mathrm{~min}$ at $65^{\circ} \mathrm{C}$. Results were visualized by autoradiography, and quantitative analysis was performed using a PhosphorImager and the ImageQuant software program (Molecular Dynamics, Sunnyvale, CA, USA). Blots were stripped with boiling $0 \cdot 5 \%$ SDS for $5 \mathrm{~min}$, and subsequent hybridization was conducted as above with ${ }^{32} \mathrm{P}-$ labelled cDNA. Northern blots performed with radiolabeled cyclophilin cDNA or $18 \mathrm{~S}$ rDNA provided RNA loading controls to which STC, MT-1, POMC and Dexras1 mRNA signals were normalized as a ratio. For the analysis of steady-state STC mRNA levels, the signal intensity of the major $4 \mathrm{~kb}$ transcript was determined as a measure of STC mRNA steady-state levels. All experiments were performed two to five times and data shown are representative of reproducibly obtained results.

\section{Nuclear run-on transcription}

The effect of Dex on the rate of gene transcription was determined using a nuclear run-on assay (Greenberg \& Bender 1997) in five separate experiments. Briefly, AtT-20 cells were seeded at a density of $7 \times 10^{6}$ cells per $175 \mathrm{~cm}^{2}$ flask in OptiMEM/charcoal-stripped FBS. After 3 days, cells were cultured for $24 \mathrm{~h}$ in fresh medium with or without $10^{-7} \mathrm{M}$ Dex. After the above treatment, cells were scraped into ice-cold PBS, pelleted at $4{ }^{\circ} \mathrm{C}$, and lysed in buffer containing $10 \mathrm{mM}$ Tris $\mathrm{HCl}, \mathrm{pH} 7 \cdot 4,10 \mathrm{mM}$ $\mathrm{NaCl}, 3 \mathrm{mM} \mathrm{MgCl}$, and 0.5\% Nonidet P-40 (NP-40). After $10 \mathrm{~min}$ at $4{ }^{\circ} \mathrm{C}$, nuclei were counted using a hemocytometer, washed twice by centrifugation at $500 \mathrm{~g}$, and then resuspended in reaction buffer $(5 \mathrm{mM}$ Tris $\mathrm{HCl}$, $\mathrm{pH} 8 \cdot 0,2 \cdot 5 \mathrm{mM} \mathrm{MgCl}_{2}$, and $\left.0 \cdot 15 \mathrm{M} \mathrm{KCl}\right)$. A $400 \mu \mathrm{l}$ volume of $5 \times 10^{7}$ nuclei was incubated for $30 \mathrm{~min}$ at $30{ }^{\circ} \mathrm{C}$ in reaction buffer supplemented with $2.5 \mathrm{mM}$ dithiothreitol, $120 \mu \mathrm{Ci}\left[\alpha_{-}{ }^{32} \mathrm{P}\right] \mathrm{CTP}(3000 \mathrm{Ci}, \mathrm{mmol}$; Amersham Pharmacia Biotech), and $0.5 \mathrm{mM}$ each of ATP, GTP and UTP. The reactions were stopped with $600 \mu \mathrm{l}$ of a solution containing $42 \mu \mathrm{g} / \mathrm{ml}$ RNase-free DNase I in $10 \mathrm{mM}$ Tris $\mathrm{HCl}, 0.5 \mathrm{M} \mathrm{NaCl}, 50 \mathrm{mM} \mathrm{MgCl}_{2}$, and $2 \mathrm{mM} \mathrm{CaCl}_{2}$. After $5 \mathrm{~min}$ at $30^{\circ} \mathrm{C}$, a $200 \mu \mathrm{l}$ volume of solution containing $10 \mathrm{mg} / \mathrm{ml}$ proteinase $\mathrm{K}$ in $0.5 \mathrm{M}$ Tris $\mathrm{HCl}, \mathrm{pH} 7 \cdot 6,0 \cdot 25 \mathrm{M}$ EDTA, and 5\% SDS was added to the reaction mixture. After $30 \mathrm{~min}$ at $42{ }^{\circ} \mathrm{C}$, total RNA was extracted using Trizol as described above, and radiolabeled transcripts were purified from unincorporated nucleotides using Sephadex G-50 columns.

Plasmid DNAs $(5 \mu \mathrm{g})$, containing cyclophilin, STC, POMC, and MT-1 cDNA, 18S rDNA fragments, or pBKSII vector alone were linearized, denatured in $0 \cdot 25 \mathrm{M}$ $\mathrm{NaOH}$ for $5 \mathrm{~min}$ at $25^{\circ} \mathrm{C}$, and neutralized in $0.4 \mathrm{M}$ Tris $\mathrm{HCl}, \mathrm{pH}$ 7.6. Denatured plasmid DNAs were treated with equivalent volumes of $20 \times$ SSC and dot-blotted onto nitrocellulose membrane (Micron Separations, Inc., Westborough, MA, USA). After baking, blots were hybridized with approximately $4 \times 10^{6}$ c.p.m. of $\alpha^{32} \mathrm{P}$ labeled AtT-20 RNA at $65^{\circ} \mathrm{C}$ overnight in $2.5 \mathrm{ml}$ of hybridization buffer used for northern blotting. Subsequently, blots were washed twice in $40 \mathrm{mM} \mathrm{Na}_{2} \mathrm{HPO}_{4}$ buffer and $0 \cdot 1 \%$ SDS for $20 \mathrm{~min}$ at room temperature, and then with $2 \times$ SSC supplemented with $0.01 \mathrm{mg} / \mathrm{ml}$ RNase A at $37^{\circ} \mathrm{C}$, followed by $40 \mathrm{mM} \mathrm{Na}_{2} \mathrm{HPO}_{4}$ and $0 \cdot 1 \%$ SDS at $37^{\circ} \mathrm{C}$. Results were analyzed as above for northern blotting.

\section{Western blot analysis}

The amounts of AtT-20 cell intracellular and secreted STC proteins were assessed by western blots. Cells were seeded at a density of $1 \times 10^{6}$ cells per $25 \mathrm{~cm}^{2}$ flask in OptiMEM/FBS. After 3 days, cells were washed and then cultured in OptiMEM alone with or without $10^{-7} \mathrm{M}$ Dex for various time periods. For secreted protein, conditioned medium was collected and then concentrated approximately fivefold using a centrifugal filter (Amicon, Beverly, CA, USA). For intracellular protein, cells were harvested from flasks using PBS containing $0.53 \mathrm{mM}$ EDTA, pelleted by centrifugation at $500 \mathrm{~g}$, and then lysed in buffer containing $50 \mathrm{mM}$ Tris $\mathrm{HCl}, \mathrm{pH} 8 \cdot 0,20 \mathrm{mM}$ EDTA, pH 8.0, $50 \mathrm{mM}$ sodium fluoride, $200 \mu \mathrm{M}$ sodium orthovanadate, $1 \mathrm{mM}$ PMSF, $10 \mu \mathrm{g} / \mathrm{ml}$ each aprotinin and leupeptin, and $1 \% \mathrm{NP}-40$. After $15 \mathrm{~min}$ at $4{ }^{\circ} \mathrm{C}$, insoluble 
material was removed by spinning the lysates at $13000 \mathrm{~g}$ for $15 \mathrm{~min}$ and the post-nuclear supernatants collected. Protein concentrations of post-nuclear supernatants were determined using the Bio-Rad Protein Assay (Bio-Rad Laboratories, Mississauga, Ontario, Canada). Fifty micrograms of post-nuclear supernatants or $60 \mu \mathrm{l}$ of concentrated conditioned medium were resolved on $8 \%$ non-reducing SDS-polyacrylamide gel and transferred to polyvinylidene difluoride membrane (Boehringer Manneheim). As a positive control, recombinant human STC was included on the protein blots. Blots were probed with rabbit anti-human STC polysera (De Niu et al. 1998), followed by horseradish peroxidase-conjugated donkey anti-rabbit antibody (Amersham Pharmacia Biotech), and subsequently developed with Western Blot Chemiluminescence Reagent Plus (NEN Life Science Products, Boston, MA, USA).

\section{Cell transfection and reporter gene assay}

AtT-20 cells were seeded at a density of $3 \times 10^{5}$ cells per six-well plate in OptiMEM/FBS and cultured for $24 \mathrm{~h}$. After incubation, cells were transfected for $24 \mathrm{~h}$ with ExGen 500 (Euromedex, Mundolsheim, France) and various luciferase reporter plasmids built with pGL3-Basic (Promega, Madison, WI, USA). The following luciferase reporter vectors were transfected in triplicate: pCMVLuc, a positive control vector containing the cytomegalovirus (CMV) enhancer and immediate early promoter fused to the luciferase gene; pGL3-STC669, a pGL3 plasmid containing $669 \mathrm{bp}$ of STC immediate $5^{\prime}$-flanking DNA, and pGL3-basic, which contains a promoterless luciferase gene as the negative control. After transfection, cells were washed twice with PBS, and then incubated for $24 \mathrm{~h}$ in OptiMEM/charcoal-stripped FBS with or without $10^{-6}$ M Dex, or UltraMEM. Luciferase activity was then measured in lysates using the Luciferase Assay System (Promega) and Berthold Lumat LB 9507 luminometer.

\section{Results}

Steady-state STC mRNA levels in AtT-20 cells are exquisitely sensitive to specific media

To determine whether expression of STC could be modulated by different growth conditions, we tested a variety of culture media in the absence or presence of FBS. Surprisingly, we observed widely different levels of STC mRNA that correlated with AtT-20 cell growth in specific cell culture media. AtT-20 cells demonstrated robust STC gene activity when grown in either OptiMEM or UltraCulture media (Fig. 1). In contrast, STC mRNA was barely detectable in AtT-20 cells cultured with UltraMEM and was quantified at $3-10 \%$ concentrations found in cells grown in either OptiMEM or
A
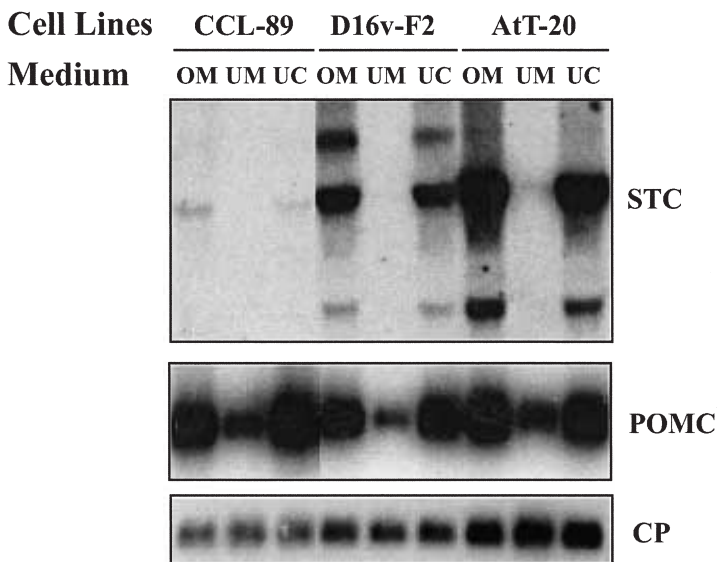

B

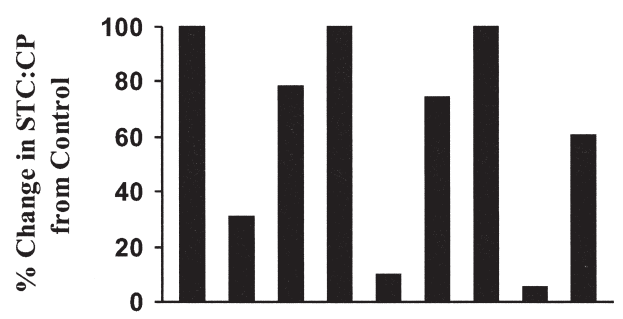

C

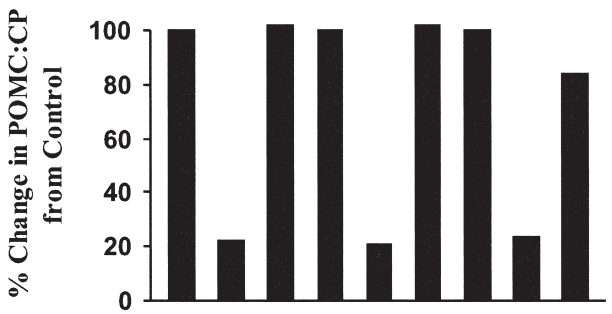

Figure 1 Steady-state STC mRNA levels in AtT-20 cells is significantly regulated by the culture medium. (A) AtT-20 cell lines from the ATCC (CCL-89 cells grow in suspension, D16 v-F2 are adherent) and from Dr M G Rosenfeld (AtT-20), were cultured to confluency in OptiMEM (OM), UltraMEM (UM) or UltraCulture (UC), each supplemented with $10 \%$ FBS. The representative autoradiographs show the mRNA abundance of STC and POMC relative to cyclophilin (CP). (B), (C) Graphical representations of the signal intensity for STC and POMC mRNA from each cell line in panel (A) after normalization to those for cyclophilin mRNA plotted as the percent change in the STC:CP and POMC:CP ratios from the values obtained in OptiMEM-cultured cells. Bars correspond to and are aligned with each lane of panel (A).

UltraCulture, despite the presence of $10 \%$ FBS and the fact that UltraMEM is considered to be a nutrient-rich medium for serum-reduced cell culture. These results were confirmed with fresh AtT-20 cells (D16 v-F2) from the ATCC and the original AtT-20 line (CCL-89) from which the adherent variant was derived. In all three cases, 
drastically reduced STC mRNA levels were observed when the cells were cultured continuously in UltraMEM, indicating that the UltraMEM-mediated repression of STC gene expression was not unique to our AtT-20 cell line and was not mediated by FBS. Interestingly, STC gene expression in the original non-adherent AtT-20 cells was significantly lower than that seen in the adherent cell line. Moreover, the steady-state POMC mRNA levels in all AtT-20 cell lines were reduced two- to fivefold when cells were grown in UltraMEM compared with the other media. One explanation for the reduction in POMC gene expression is that UltraMEM contained glucocorticoids, as it is well established that corticosteroids exert negative feedback repression on POMC transcription and ACTH release from corticotropes, including AtT-20 cells (Drouin et al. 1989, 1993). It should be noted that the composition of these nutrient-rich media was not available.

In addition to the reduction in STC and POMC mRNA levels, UltraMEM induced other distinct morphological changes in the adherent AtT-20 corticotrope cell line. In OptiMEM, AtT-20 cells consistently appeared as large clusters of rounded cells that grew on top of cells with a stellate morphology, whereas they adopted a singular stellate morphology in UltraMEM (Fig. 2A). In addition to radical alterations in morphology, these nutrient-rich media had a significant impact on AtT-20 cell growth. Analysis of the proliferation rate over a 7-day period indicated that AtT-20 cells grew three to nine times more slowly in UltraMEM compared with parallel cultures in OptiMEM (Fig. 2B). This result was also another indication that glucocorticoids were present in UltraMEM, because they have been demonstrated to attenuate AtT-20 cell growth (van Wijk et al. 1995). We also observed that the exponential growth of AtT-20 cells in OptiMEM (Fig. 2B) was accompanied by an increase in steady-state STC mRNA levels (Fig. 2C-D). During this period of rapid growth, the abundance of STC mRNA gradually increased, to be six- to 19-fold greater at maximum cell density on day 7 compared with day 0 (Fig. $2 \mathrm{C}-\mathrm{D})$. In contrast, there were no significant increases in POMC mRNA levels during this period of cell growth (Fig. 2C-D). Taken together, these results suggest that AtT-20 cells are significantly altered in their growth potential, morphology and steady-state level of STC mRNA when cultured in the presence of different nutrient-rich media.

\section{The apparent loss of STC gene expression in UltraMEM is reversible}

Further investigation was performed to determine whether the virtually complete abrogation of STC mRNA expression in AtT-20 cells, mediated by UltraMEM, was reversible. To test this, AtT-20 cells were cultured in UltraMEM, washed extensively to remove factors in UltraMEM that were potentially down-regulating STC gene expression, and then switched to OptiMEM. Alternatively, cells were cultured in OptiMEM, washed, and then switched to UltraMEM. In two independent experiments, the switch from UltraMEM to OptiMEM resulted in a profound eight- to 36-fold increase in STC mRNA abundance (Fig. 3A), whereas the reverse switch caused a 6- to 13-fold decrease and almost complete loss of STC mRNA (Fig. 3B). These results clearly suggested that a component of UltraMEM was responsible for significantly down-regulating STC and POMC gene expression.

\section{Dexamethasone induces dramatic down-regulation of STC gene expression in AtT-20 cells}

As mentioned above, the down-regulation in STC and POMC gene expression observed in AtT-20 cells cultured in UltraMEM may have reflected the presence of glucocorticoids (Drouin et al. 1989, 1993). To test this, we examined the effect of Dex on the abundance of STC and POMC mRNA levels in AtT-20 cells cultured in OptiMEM in nine independent experiments (Fig. 4). Dexamethasone dramatically reduced steady-state STC mRNA levels within $4 \mathrm{~h}$; this effect was routinely maximal at $24 \mathrm{~h}$, with a five- to 22-fold loss of STC mRNA signals in the presence of $10^{-7} \mathrm{M}$ Dex. Consistent with reports demonstrating the sensitivity of POMC gene expression to Dex (Drouin et al. 1989, 1993), POMC mRNA levels were consistently reduced twofold by $48 \mathrm{~h}$ (Fig. 4). These results clearly indicated that $S T C$ gene activity was much more sensitive to glucocorticoid repression than was the $P O M C$ gene. As a further control for glucocorticoid activity, we evaluated the expression of the Dexras 1 gene, a member of the Ras superfamily of GTPase genes, as it has been shown to be rapidly induced in AtT-20 cells upon addition of Dex (Kemppainen \& Behrend 1998). Consistent with a previous report (Kemppainen et al. 1998), Dexras1 mRNA accumulation was significantly induced in AtT-20 cells, routinely reaching 200- to 300-fold greater values within $3 \mathrm{~h}$ after Dex treatment (Fig. 4). The induction of Dexras1 gene expression preceded the reduction in STC mRNA levels and confirmed the rapid gene-stimulatory effects of glucocorticoids on AtT-20 cells.

Given the dramatic changes induced by the synthetic glucocorticoid on STC mRNA abundance, we investigated whether other steroid hormones could induce similar changes in AtT-20 cells. In two independent experiments, the hormones DHT, $17 \beta$-estradiol and progesterone produced only modest (less than twofold) changes in STC mRNA levels, compared with the five- to eightfold reduction by Dex (Fig. 5).

To determine whether glucocorticoid repression of STC mRNA accumulation was specific to AtT-20 cells, two independent experiments were carried out with the human fibrosarcoma cell line HT1080, which maintains high steady-state STC mRNA levels (Chang et al. 1995). 


\section{A}

\section{OptiMEM}

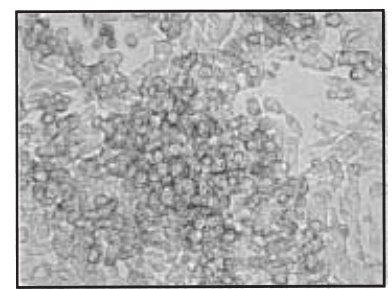

\section{UltraMEM}

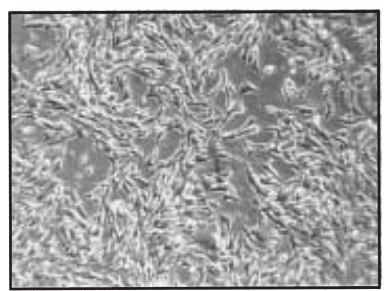

B

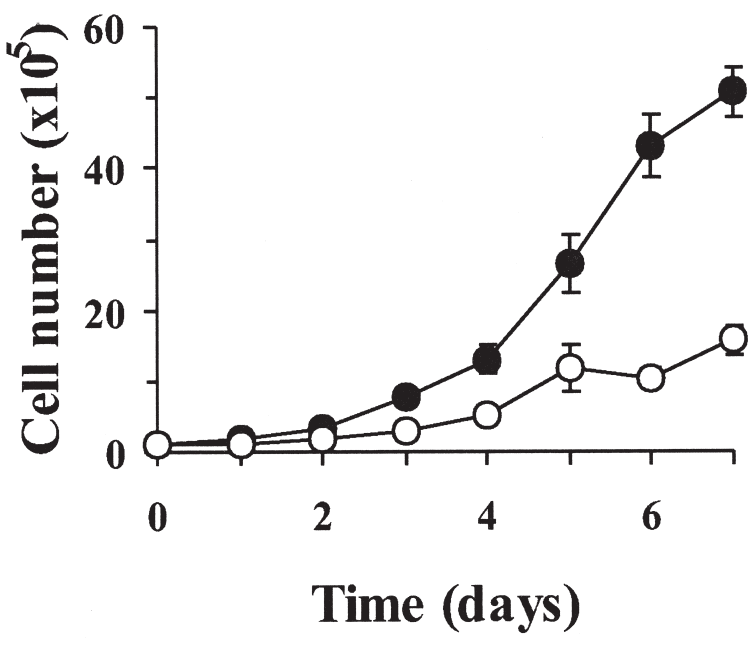

D
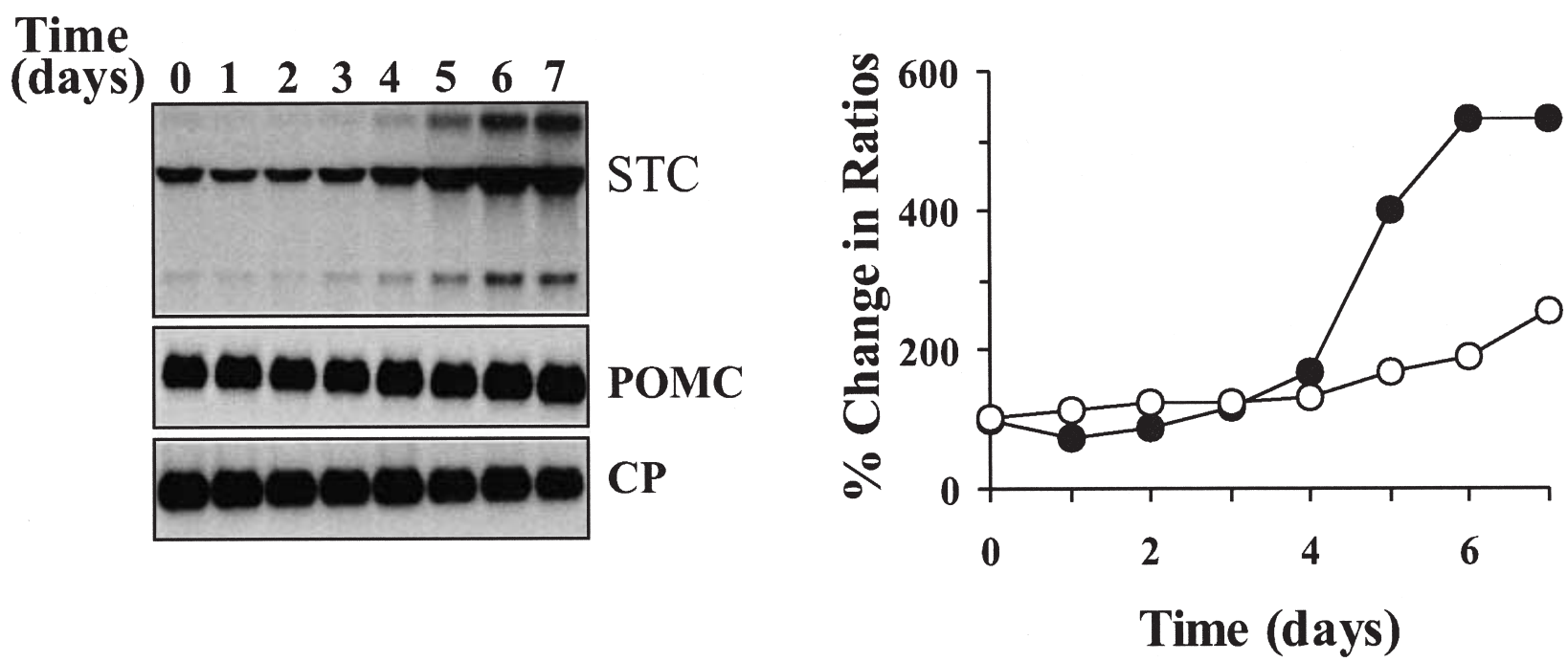

Figure 2 Culture medium induces dramatic alterations in morphology, growth rate and STC gene expression in AtT-20 cells. (A) Phasecontrast micrographs of AtT-20 cells grown in either OptiMEM/FCS or UltraMEM/FCS. AtT-20 cells appear as large clusters of rounded cells that grow on top of cells with a stellate morphology when cultured in OptiMEM/FCS. In contrast, AtT-20 cells adopt a singular stellate morphology in UltraMEM. (B) AtT-20 cells were seeded at $1 \times 10^{5}$ cells per culture dish containing either OptiMEM/FBS or UltraMEM/FBS and then harvested at the indicated times for cell counting. The plot, which was representative of multiple experiments, compares the rate of growth of AtT-20 cells in OptiMEM $(-)$ and UltraCulture $(\bigcirc)$. The results shown were the mean \pm S.D. of triplicate samples. (C) Approximately $3 \times 10^{5}$ AtT-20 cells were seeded per culture dish containing OptiMEM/FCS and then harvested for RNA extraction at the times indicated. A typical northern blot shows the steady-state level of STC and POMC mRNA relative to that of cyclophilin. (D) The change in STC and POMC mRNA levels in panel (C) were quantitated, normalized to cyclophilin mRNA and plotted as the percent change in the STC:CP $(\bullet)$ and POMC:CP $(\bigcirc)$ ratios relative to day 0 values.

The HT1080 cells, like AtT-20 cells, routinely exhibited a significant down-regulation in the abundance of STC mRNA, with a maximal fivefold reduction at $24 \mathrm{~h}$ after treatment (Fig. 6). Thus the strong repressive effects of glucocorticoids on STC gene expression did not occur via a mechanism restricted to AtT-20 cells.

\section{Effects of dexamethasone on STC protein in AtT-20 cells}

We next assessed whether the repressive effects of Dex on STC mRNA abundance in AtT-20 cells resulted in similar changes in STC protein concentrations. We simultaneously examined intracellular and secreted STC in 
A

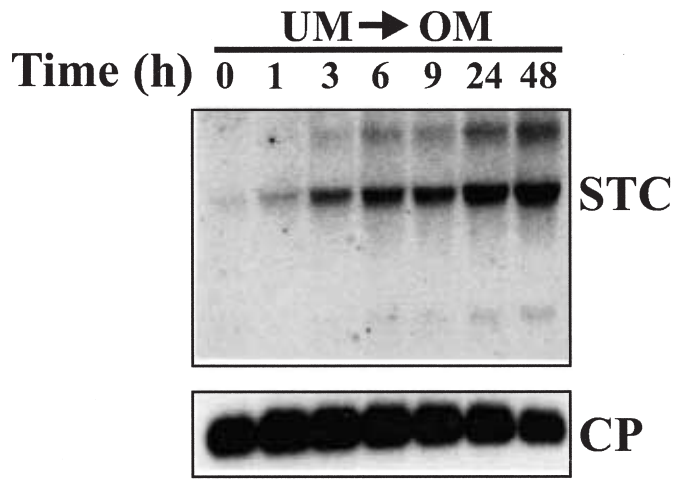

B

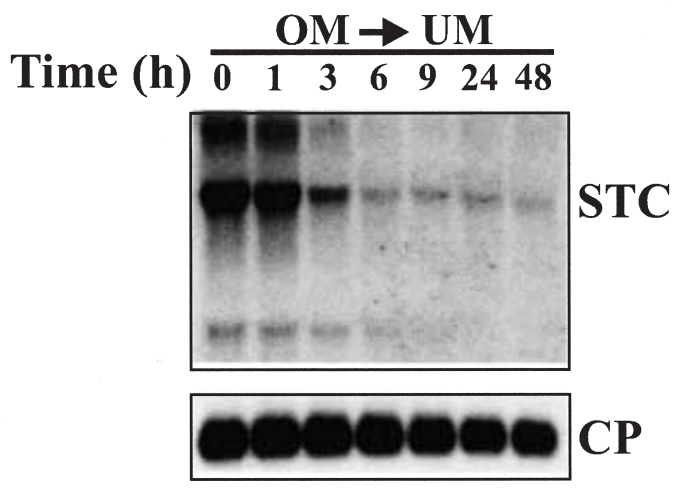

C

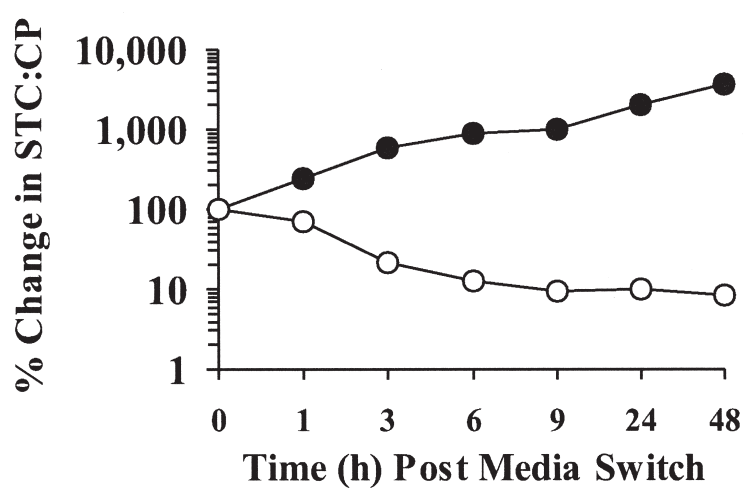

Figure 3 Loss of STC gene expression in AtT-20 cells under UltraMEM (UM) culture conditions is reversible. (A), (B) AtT-20 cells were cultured for 3 days in OptiMEM/charcoal-stripped FCS (or UltraMEM/FCS), washed, the medium switched to UltraMEM/ FCS (or OptiMEM/FCS), and the cells harvested at the indicated times for RNA extraction. (A), (B) Typical autoradiographic results indicating the mRNA levels of STC relative to cyclophilin (CP). (C) Graphical representation of the data in panels (A) (UltraMEM to OptiMEM; O) and (B) (OptiMEM to UltraMEM; $O$ ), showing the change in normalized STC mRNA at the indicated times as the percent change from time 0 , on a log scale.

Dex-treated cells. Dexamethasone did not affect the abundance of intracellular STC protein in the post-nuclear fraction of AtT-20 cells (Fig. 7B). Similarly, AtT-20

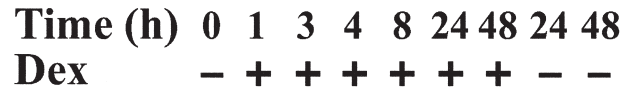

Dex

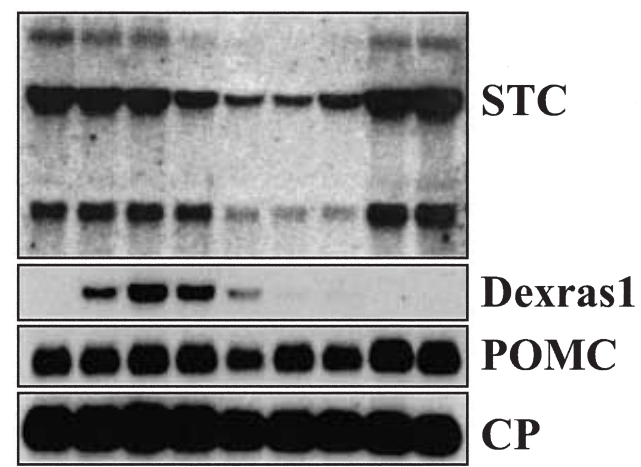

Figure 4 Dexamethasone represses STC gene expression in AtT-20 cells. AtT-20 cells were treated with $10^{-7} \mathrm{M}$ Dex in OptiMEM/charcoal-stripped FCS for the times indicated and then harvested for RNA extraction. A northern blot, representative of several experiments, shows the steady-state mRNA levels of STC, Dexras1, and POMC relative to cyclophilin.

secretion of STC into the culture medium was not perturbed by Dex treatment over the $30-\mathrm{h}$ treatment period, as determined by quantitation of the bands on westerns blots (Fig. 7B). However, further investigation using a human STC (hSTC) radioimmunoassay (De Niu et al. 2000) found that Dex significantly down-regulated the level of STC in conditioned medium by $48 \mathrm{~h}$ after treatment (Fig. 7C). Thus the Dex-mediated changes in abundance of STC mRNA were accompanied by a significantly delayed reduction in secreted STC, possibly reflecting the long half-life of the hormone STC under tissue culture conditions.

The GR antagonist RU486 abrogates repression of STC by glucocorticoids

To confirm that Dex repressed STC gene expression via activation of the GR, we assessed the ability of the glucocorticoid antagonist, RU486, to overcome the glucocorticoid-mediated reduction in AtT-20 steady-state STC mRNA levels. The RU486 treatments were carried out in cells cultured in UltraMEM, in which STC mRNA levels are suppressed without the addition of Dex. Glucocorticoid radioimmunoassay of UltraMEM indicated that it contained at least $0 \cdot 8 \mu \mathrm{M}$ hydrocortisone, whereas OptiMEM and UltraCulture do not contain glucocorticoids. In five independent experiments, the GR antagonist routinely increased steady-state STC mRNA levels in UltraMEM-cultured AtT-20 cells, indicating that it rescued STC gene expression in the presence of glucocorticoid-rich media (Fig. 8A). These findings were supported by data from experiments of RU-486 treatment of AtT-20 cells when cultured in OptiMEM 
A

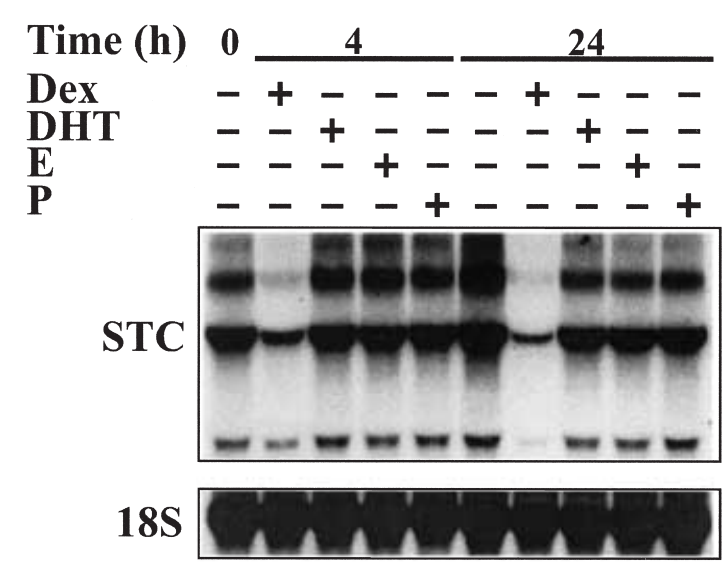

B

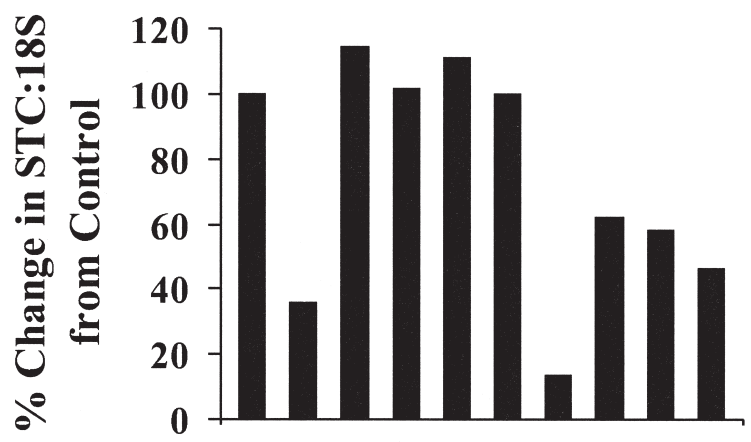

Figure 5 STC gene expression demonstrates differential responsivity to steroid hormones. (A) AtT-20 cells cultured in OptiMEM/charcoal-stripped FCS were treated with $10^{-7} \mathrm{M}$ Dex, $10^{-7} \mathrm{M} \mathrm{DHT}, 10^{-7} \mathrm{M} \beta$-estradiol (E), or $10^{-7} \mathrm{M}$ progesterone (P) for 4 and $24 \mathrm{~h}$. The representative autoradiograph shows the abundance of STC mRNA relative to $18 \mathrm{~S}$ rRNA. (B) Numerical depiction of the normalized mRNA signals in panel (A), indicating the percent change in steady-state STC mRNA levels compared with untreated cells at each time point. Bars correspond to and are aligned with each lane of panel (A). DHT, $\beta$-estradiol and progesterone have a minor effect on STC expression, in contrast to the strong inhibition caused by Dex.

supplemented with Dex. The GR antagonist consistently abrogated the Dex-mediated down-regulation of STC mRNA levels in AtT-20 cells (Fig. 8B). Steady-state STC mRNA levels in AtT-20 cells consistently reached $80 \%$ of control levels when the cells were treated with both RU486 and Dex for $48 \mathrm{~h}$, compared with the six- to 12-fold decrease in STC mRNA abundance seen in cells treated with Dex alone. RU486 had no significant effect on the accumulation of STC mRNA compared with that in untreated cells. These data showed that Dex repression of the abundance of STC mRNA in AtT-20 cells was mediated by the GR.
A
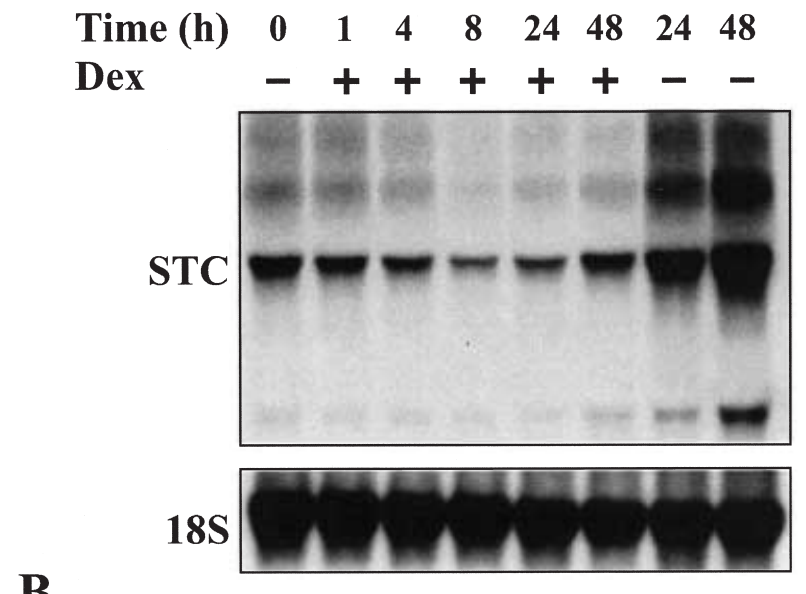

B

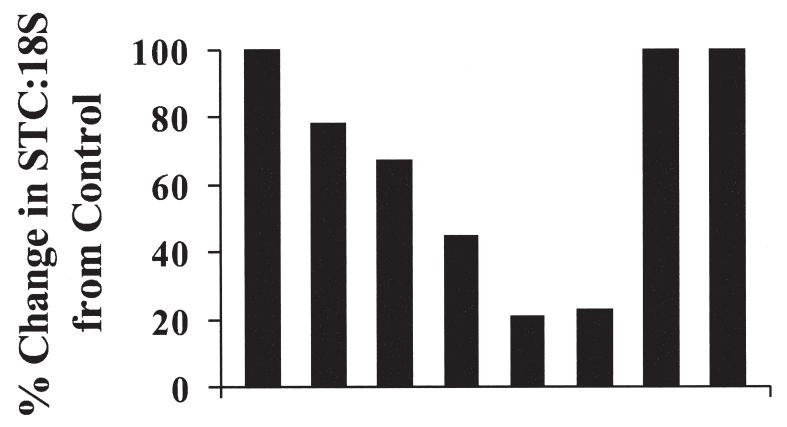

Figure 6 Dexamethasone repression of STC expression is not limited to AtT-20 cells. (A) HT1080 cells were treated with $10^{-6} \mathrm{M}$ Dex in OptiMEM/charcoal-stripped FCS for the times indicated and then harvested for RNA isolation. Typical northern blot, indicating the steady-state mRNA levels of STC relative to $18 \mathrm{~S}$ rRNA. (B) Results for STC mRNA from panel (A), quantitated and normalized to the $18 \mathrm{~S}$ rRNA signal and plotted as the percent change in STC:18S ratios relative to untreated cells at 0, 24, and $48 \mathrm{~h}$. The bars correspond to each lane of the northern blot in panel (A). Dex decreased HT1080 STC mRNA levels by $80 \%$ after $24 \mathrm{~h}$ treatment.

Activation of cAMP-signaling pathway antagonizes the repressive effects of hydrocortisone on STC $m R N A$ levels in UltraMEM-cultured AtT-20 cells

In previous studies, activation of the cAMP signaling pathway was reported to alter $P O M C$ gene activity in AtT-20 cells (Knight et al. 1987, Lundblad et al. 1988, Autelitano et al. 1989). Given that gene expression of both $S T C$ and POMC demonstrated sensitivity to glucocorticoids, we investigated whether induction of the protein kinase A (PKA) pathway could alter the response of the STC gene to glucocorticoids. Briefly, intracellular cAMP levels were increased in UltraMEM-cultured AtT-20 cells by treatment with the adenylate cyclase activators: forskolin or CRF, or the cAMP analog 8Br-cAMP. The drug forskolin stimulates the adenylate cyclase system by 
constitutive activation of adenylate cyclase (Tang \& Hurley 1998), whereas CRF induces the adenylate cyclase pathway via binding to CRF receptors expressed on corticotrope cells (Luini et al. 1985, Reisine et al. 1985). In two independent experiments, northern blot analysis indicated that the cAMP-inducing agents dramatically increased STC mRNA levels in UltraMEM-cultured

\section{A}

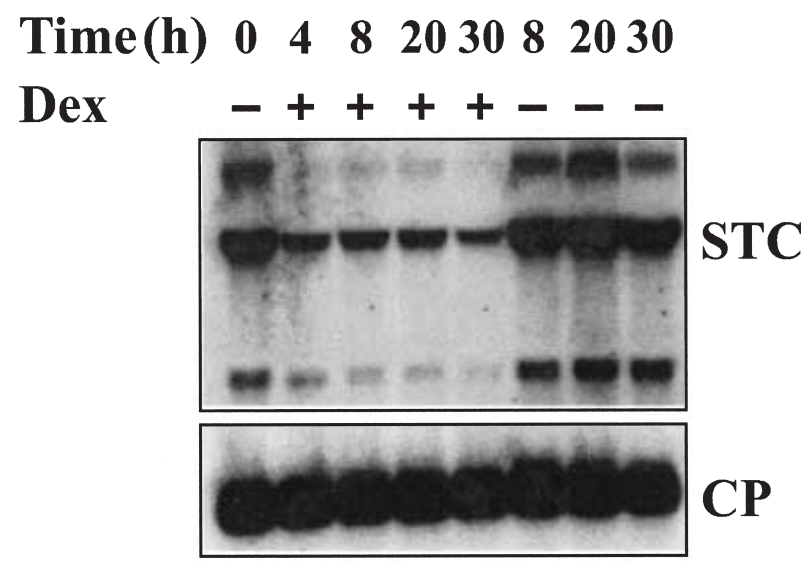

B

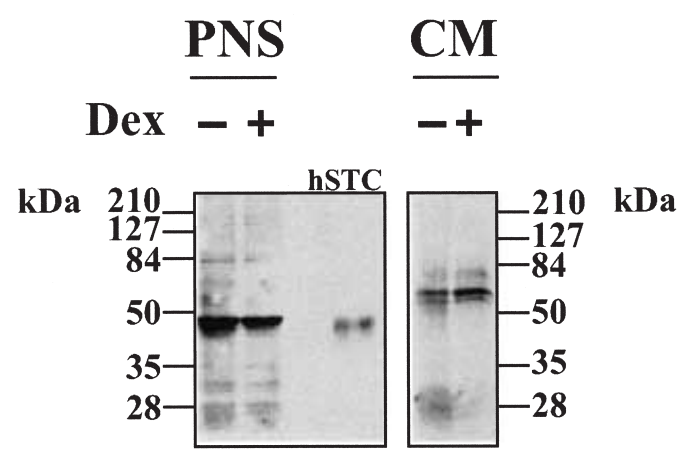

C

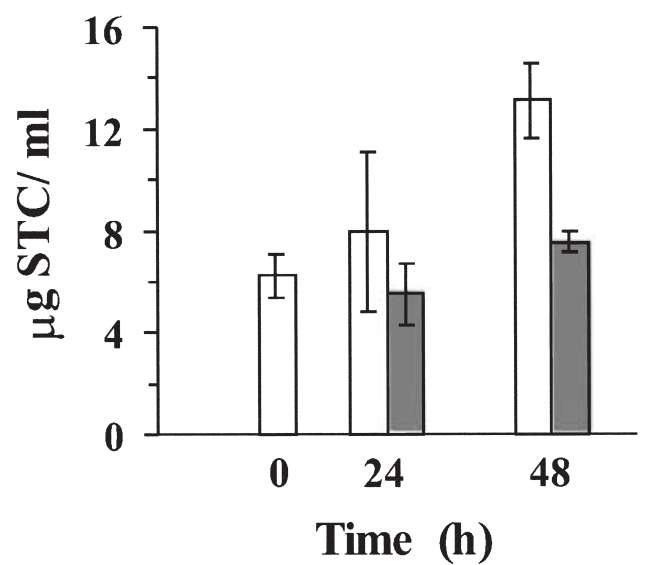

AtT-20 cells, routinely reaching maximum values $4 \mathrm{~h}$ after the addition of these agents and returning to basal values at $24 \mathrm{~h}$ after treatment (Fig. 9). The level of STC mRNA induction in UltraMEM-cultured AtT-20 cells was threeto eightfold with CRF, five- to 15 -fold with forskolin, and seven- to 30-fold with 8Br-cAMP. In contrast, stimulation of UltraMEM-cultured AtT-20 cells with phorbol 12myristate 13-acetate, a protein kinase C (PKC) activator, failed to induce STC mRNA expression (data not shown), suggesting that stimulation of the PKC pathway and the subsequent increase in intracellular $\mathrm{Ca}^{2+}$ concentrations cannot rescue STC gene expression. Consistent with this finding, a fourfold increase in $\mathrm{CaCl}_{2}$ concentration in UltraMEM was insufficient to induce STC mRNA levels in AtT-20 cells (data not shown), implying that extracellular $\mathrm{Ca}^{2+}$ could not antagonize the repressive effects of Dex on STC gene expression. In summary, these findings strongly suggest that induction of the intracellular cAMP pathway can specifically overcome the glucocorticoidmediated inhibition of STC gene expression in AtT-20 cells.

\section{Dexamethasone does not alter STC reporter gene expression}

The Dex-mediated repression in steady-state STC mRNA levels may be secondary to a reduction in STC gene transcription. To examine this, AtT-20 cells were transiently transfected with pGL3 mSTC669, a pGL3 plasmid with the luciferase gene under the control of a $669 \mathrm{bp}$ region of the mSTC proximal promoter. After transfection, cells were cultured in either UltraMEM or OptiMEM, with or without Dex, to determine the effect of glucocorticoids on STC promoter activity in three independent experiments. The presence of glucocorticoids in the culture medium routinely did not modulate the CMV promoter activity of the pCMV-luciferase positive control reporter gene, indicating that glucocorticoids were

Figure 7 Dex repression of STC is not apparent at the protein level until $48 \mathrm{~h}$ after treatment. (A) Cells were cultured in OptiMEM/charcoal-stripped FBS in the presence or absence of $10^{-7} \mathrm{M}$ Dex for the indicated periods of time. The

autoradiograph illustrates STC steady-state mRNA levels relative to cyclophilin mRNA. (B) Post-nuclear supernatants (PNS) and conditioned media (CM) were prepared from AtT-20 cells cultured in OptiMEM with or without $10^{-7} \mathrm{M}$ Dex treatment for $30 \mathrm{~h}$ (cells from which RNA was isolated and used to generate panel (A)). Representative western blots loaded with $50 \mu \mathrm{g}$ post-nuclear supernatants protein per sample and $60 \mu \mathrm{l}$ conditioned medium protein per sample indicated STC protein concentrations. A lane of recombinant human STC (hSTC) was loaded as a size control. (C) Cells were cultured in OptiMEM/charcoal-stripped FBS for 3 days and then treated with $(\square)$ or without $(\square) 10^{-7} \mathrm{M}$ Dex for the times indicated. The concentration of STC in conditioned medium was measured using an hSTC radioimmunoassay. The results shown are the means \pm S.D. of triplicate samples; they reveal a significant loss of STC from the media after $48 \mathrm{~h}$ in the presence of Dex. 
not globally suppressing transcription (Fig. 10A). In cells transfected with pGL3 mSTC669, glucocorticoids consistently had no effect on STC proximal promoter activity. These results clearly indicated that GR did not directly

A

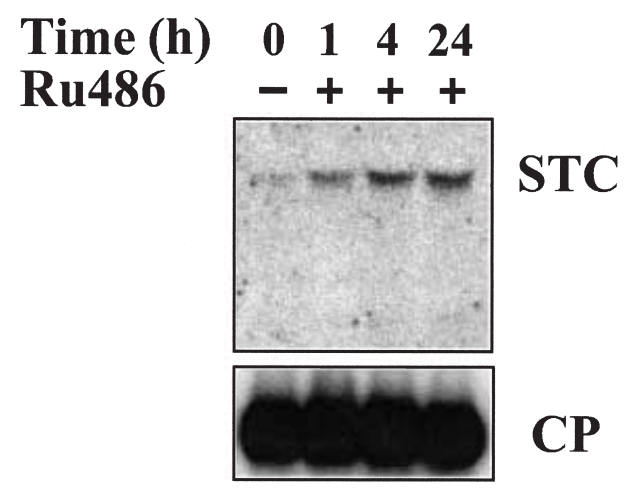

B

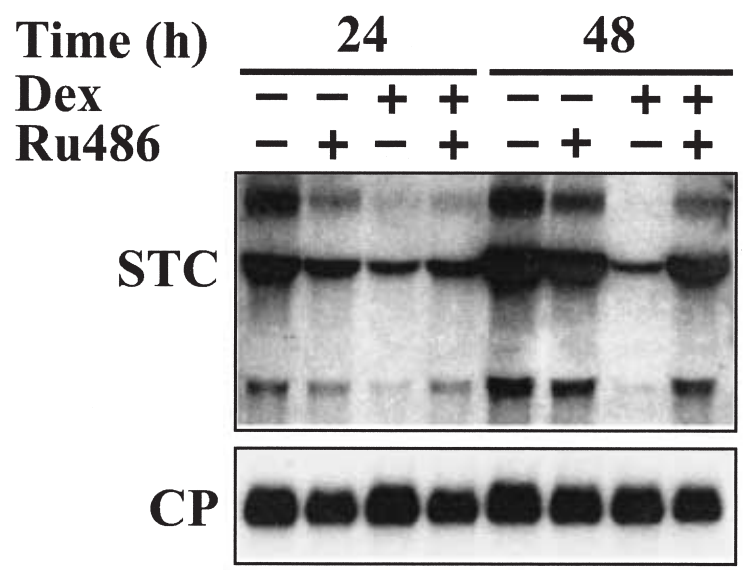

C

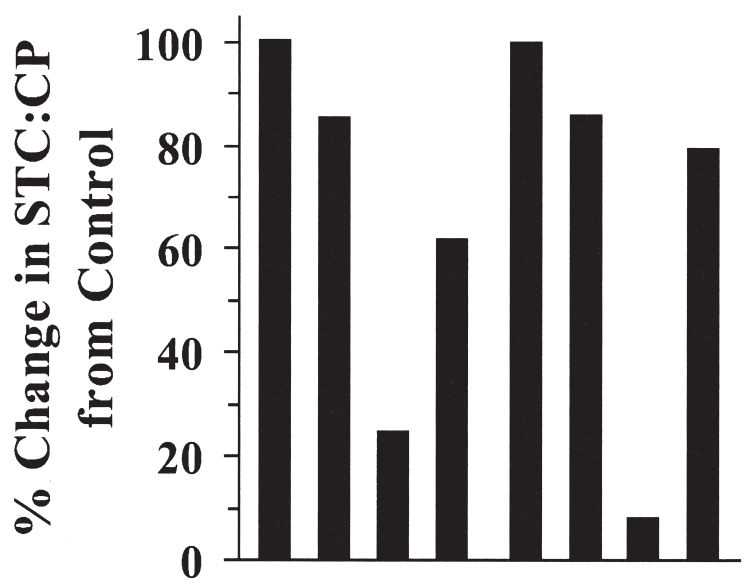

down-regulate the strong STC proximal promoter activity in AtT-20 cells, suggesting that transcriptional inhibition may not be responsible for the Dex-mediated downregulation of steady-state STC mRNA levels.

\section{Dexamethasone does not alter the rate of STC gene transcription}

The lack of glucocorticoid effects on mSTC proximal promoter activity did not preclude the possibility of a negative effect on transcription mediated by other parts of the STC gene. To address this possibility, we performed nuclear run-on assays. Briefly, the rate of nascent STC transcript formation was assessed in nuclei isolated from AtT-20 cells cultured in the presence or absence of Dex for $24 \mathrm{~h}$ in OptiMEM. In untreated cells, the rate of STC gene transcription was barely detectable relative to $18 \mathrm{~S}$ rRNA, and this routinely remained unaltered, as determined by quantitative PhosphorImager analysis, after Dex treatment in four independent experiments (Fig. 11B1). Similar results were observed for cyclophilin $(C P)$ gene transcription. As observed by others (Mayo et al. 1981, Drouin et al. 1989, 1993), Dex dramatically reduced $P O M C$ transcription and enhanced MT-1 gene transcription by two- to 12 -fold and three- to 13 -fold, respectively, indicating that Dex treatment was effective and that the nuclear run-on assays were functional. Although we cannot conclude definitively that glucocorticoids downregulate $S T C$ gene transcription, it seems unlikely that the large decrease in STC mRNA accumulation caused by glucocorticoids is due solely to direct transcriptional inhibition.

Dexamethasone-mediated decrease in AtT-20 STC mRNA levels requires current gene transcription

Because glucocorticoids failed to have an effect on STC gene transcription, we investigated whether glucocorticoids were acting at the post-transcriptional level to reduce steady-state mRNA levels. In an effort to determine whether Dex repression was due to a change in STC mRNA stability, cells were treated with Dex, Act D, or both, and changes in STC mRNA accumulation were assessed. As a control, the level of MT-1 mRNA was

Figure 8 RU486 antagonizes the Dex-mediated down-regulation of STC mRNA levels in AtT-20 cells. (A) AtT-20 cells cultured in UltraMEM/FCS were treated with $10^{-7} \mathrm{M}$ RU486 at the times indicated and then harvested for RNA analysis. RU486 rescued STC mRNA after just $1 \mathrm{~h}$ of treatment. (B) AtT-20 cells cultured in OptiMEM/charcoal-stripped FCS were treated with $10^{-7} \mathrm{M}$ Dex, $10^{-7} \mathrm{M}$ RU486, or both, and then harvested at 24 and $48 \mathrm{~h}$ after treatment, for northern analysis. (C) The results in panel (B) were quantitated as described in Materials and Methods and presented as the percent change in the STC:Cyclophilin (CP) ratio relative to untreated cells for corresponding time periods. The bars are aligned with corresponding lanes of panel (B). 
A
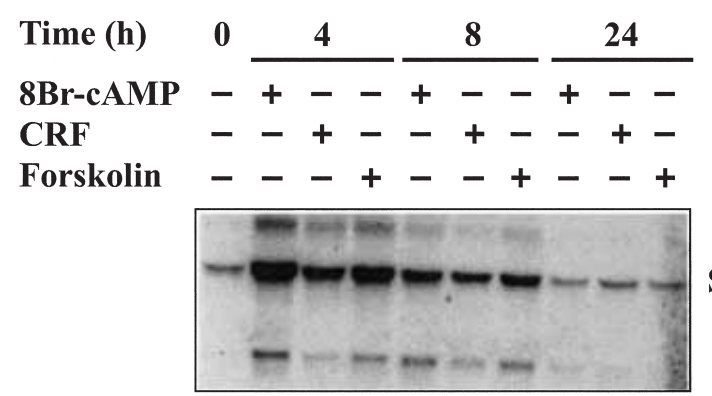

STC

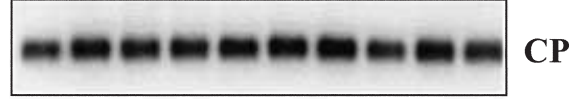

B

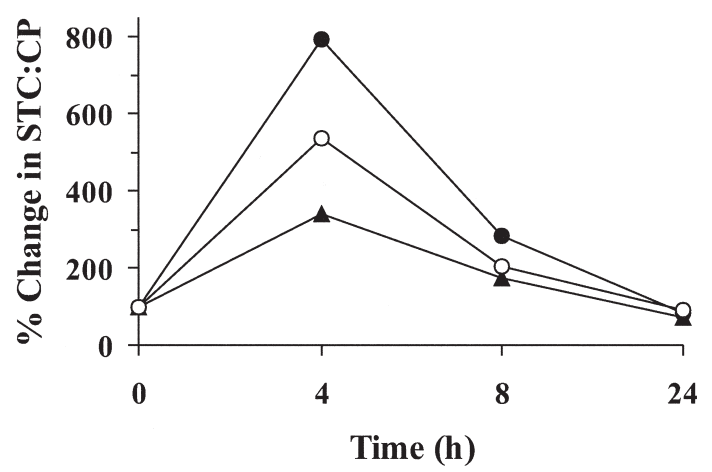

Figure 9 Activation of the cAMP-signaling pathway transiently antagonizes repression of STC gene expression in UltraMEMcultured AtT-20 cells. (A) AtT-20 cells cultured in UltraMEM/FCS were treated with $5 \mathrm{mM} 8 \mathrm{Br}-\operatorname{cAMP}(\bullet), 10^{-7} \mathrm{M} \mathrm{CRF}(\boldsymbol{\Delta})$, or $10^{-5} \mathrm{M}$ forskolin $(\bigcirc)$ and then harvested at the times indicated, for northern blot analysis. The autoradiographic signals in panel (A) were quantitated, normalized as described previously, and plotted as the percent change in the STC:cyclophilin (CP) ratio from time $0 \mathrm{~h}$.

measured in parallel. The transcriptional inhibitor, Act D, did not appreciably alter STC transcript accumulation, because mRNA levels were at least $65 \%$ of controls $24 \mathrm{~h}$ after Dex treatment (Fig. 11), indicating that STC mRNA was remarkably stable. In contrast, the MT-1 mRNA level was diminished by $72 \%$ and $93 \%$ at $14 \mathrm{~h}$ and $24 \mathrm{~h}$, respectively, demonstrating that the Act D-treated cells had undergone an arrest in gene transcription.

The Dex-mediated repression of AtT-20 STC mRNA levels was unexpectedly attenuated at $14 \mathrm{~h}$ and $24 \mathrm{~h}$ after addition of Act D (Fig. 11). Co-incubation of Act D and Dex abrogated the repressive effect of Dex, by maintaining STC mRNA abundance at nearly $70 \%$ of control levels. Dexamethasone alone reproducibly diminished steadystate STC mRNA to virtually undetectable levels within
A

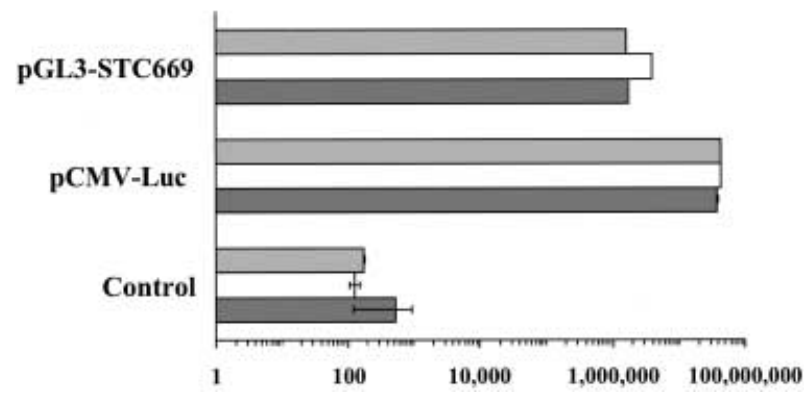

B

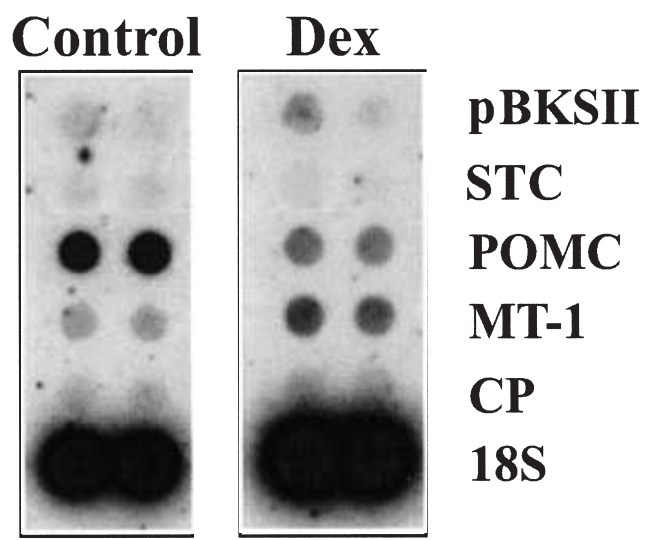

Figure 10 Dexamethasone does not affect STC gene transcription in AtT-20 cells. (A) Cells in OptiMEM were transfected with luciferase reporter genes, washed, and incubated for $24 \mathrm{~h}$ in OptiMEM (light-shaded bars), OptiMEM with $10^{-7} \mathrm{M}$ Dex (open bars), or UltraMEM (dark-filled bars). Luciferase activity was determined as described in Materials and Methods and expressed as the mean \pm S.D. of triplicate cultures. pGL3-STC669 carried $669 \mathrm{bp}$ of the mouse STC proximal promoter region and produced equivalent luciferase activity under all culture conditions, which was significantly greater than the promoterless Control luciferase reporter, pGL3-Basic and less than the positive control plasmid, pCMV-Luc. (B) Cells were cultured in OptiMEM with or without $10^{-7} \mathrm{M}$ Dex for $24 \mathrm{~h}$. Nuclei were isolated from cells and nuclear run-on assays were performed as described in Materials and Methods. The representative autoradiogram indicates hybridization of radiolabeled RNA to membranes containing duplicate dots of cDNAs for STC, POMC, MT-1, cyclophilin (CP), and $18 \mathrm{~S}$ rRNA. The intensity of the signal was indicative of the level of transcription compared with non-specific hybridization to pBKSII.

$24 \mathrm{~h}$. Consistent with the findings of previous studies (Mayo \& Palmiter 1981), expression of MT-1 increased approximately twofold in response to Dex treatment. After $48 \mathrm{~h}$ of Act D treatment, the STC mRNA signal was almost lost (85\%), presumably because of normal mRNA metabolism. Therefore, the ability of Act D to rescue Dex-mediated repression of STC mRNA levels was eventually overcome by the normal mRNA degradative pathways leading to loss of all mRNAs. Similar experiments were carried out with other transcriptional 
A

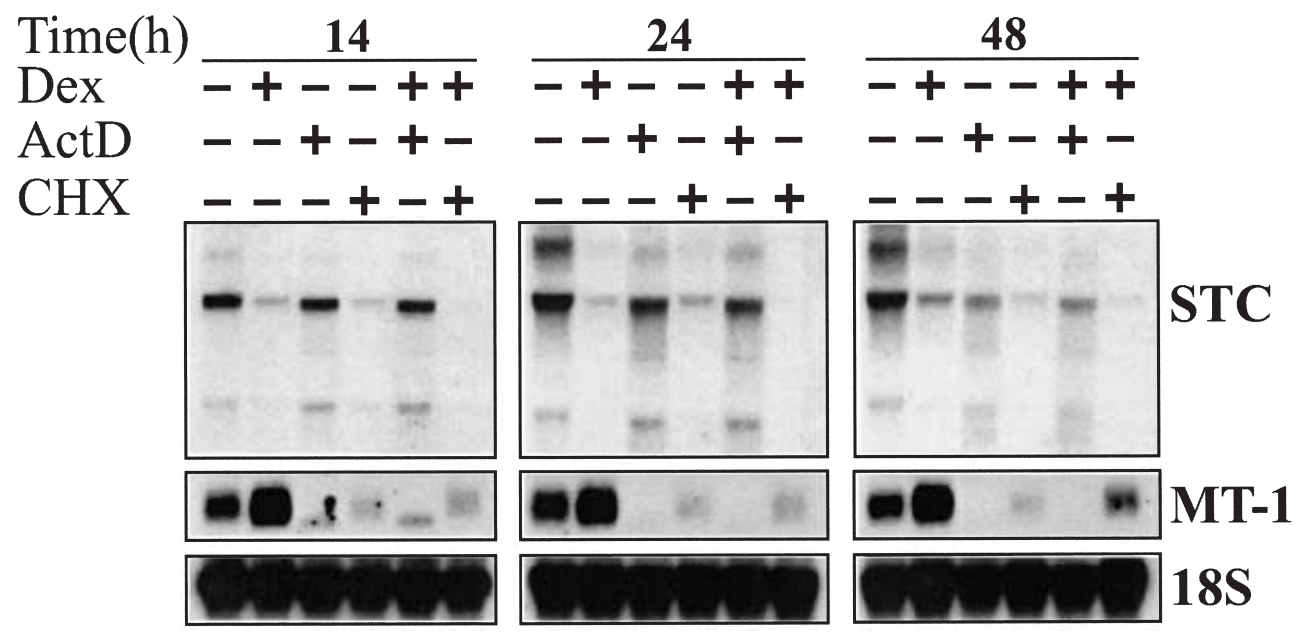

B

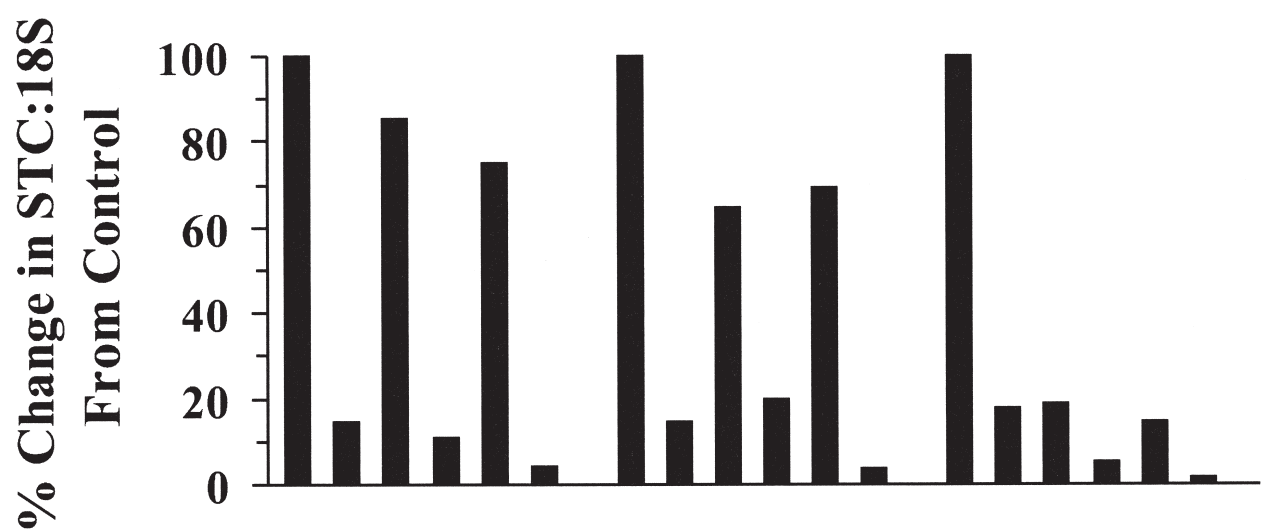

C

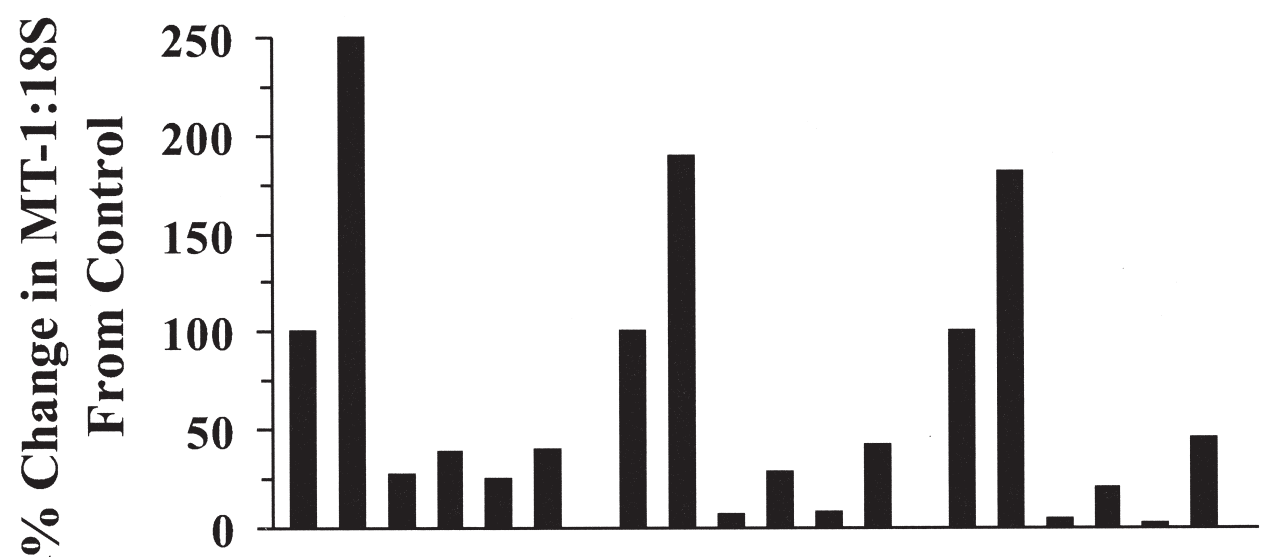

Figure 11 Dexamethasone-mediated decrease in STC mRNA levels in AtT-20 cells requires current gene transcription.

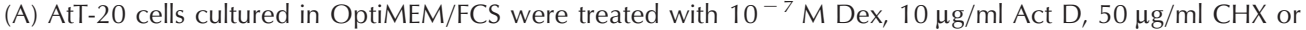
combinations of these, and then harvested at the times indicated, for northern blotting. The northerns blots $(30 \mu \mathrm{g}$ total RNA/lane) show the steady-state mRNA levels of STC and MT-1 relative to 18S rRNA in AtT-20 cells at 14, 24, and $48 \mathrm{~h}$ after the indicated treatments. (B), (C) The results for STC and MT-1 mRNA in panel (A) were normalized against the 18S rRNA signal and plotted as the percent change in the STC:18S and MT-1:18S ratios compared with untreated cells at corresponding time periods. Each bar is aligned with the corresponding lane in panel (A). 
inhibitors, $\alpha$-amanitin and DRB, and we obtained essentially identical results with respect to STC mRNA accumulation.

In addition to Act D, we evaluated the effect of the protein synthesis inhibitor, CHX, on Dex-mediated repression of STC mRNA accumulation. In contrast to Act D, but similar to Dex, CHX alone reduced STC mRNA to undetectable levels after $14 \mathrm{~h}$, which suggested that $\mathrm{CHX}$ blocked the translation of proteins required for STC gene transcription or those required for STC mRNA stability. CHX obviously did not rescue STC mRNA from Dex down-regulation even though it has been shown to enhance the stability of several different mRNAs (Philippe \& Missotten 1990, Yoon et al. 1998, Rahgeb et al. 1999, Soloff et al. 2000, Wang et al. 2000). Because of the unexpected stabilizing effect of transcriptional inhibitors on STC mRNA, it was not possible to determine its half-life accurately in the presence of glucocorticoids. There was no significant change in STC mRNA abundance over the 24-h period in Act D; however, cell viability was significantly compromised and, consequently, it was not possible to obtain an accurate indication of the STC mRNA half-life. Nevertheless, in the absence of glucocorticoids, it was clear that STC mRNA was longlived. The results are consistent with a mechanism in which Dex destabilization of STC mRNA is dependent upon transcription of another gene(s).

\section{Steady-state STC mRNA levels in AtT-20 cells are down-regulated by Dex via induction of early gene(s)}

In an effort to examine the rapidity of the Dex effect on STC mRNA, we followed the temporal onset of this inhibition after treatment with Act D as a countermeasure. As shown above, Act D antagonized the inhibitory effect of Dex on STC mRNA abundance and prolonged its T1/2. Cells were pretreated for $0 \cdot 5,1,2,5$ and $8 \mathrm{~h}$ with Dex, followed by $24 \mathrm{~h}$ in Act D-containing media, after which STC mRNA levels were assessed (Fig. 12A). As controls, parallel cultures were exposed to Dex or Act D alone, or Dex plus Act D simultaneously. The temporal pattern of STC mRNA loss after different times of exposure to Dex followed by $24 \mathrm{~h}$ with Act D closely mirrored the changes seen in cells given Dex alone (Fig. 12A,B). In AtT-20 cells treated for $1 \mathrm{~h}$ with Dex followed by Act D, steady-state STC mRNA levels were reduced by $50 \%$, with almost identical results obtained in the presence of Dex alone for $1 \mathrm{~h}$. Therefore, Act D could not rescue Dex-mediated repression of STC mRNA accumulation, even after only a 1-h pretreatment, consistent with the notion that GR had induced an early gene product(s) that destabilized STC mRNA. In contrast, Act D significantly reduced MT-1 mRNA accumulation (by 74\%), despite a $0.5 \mathrm{~h}$ pretreatment with Dex, indicating that transcription was essential for Dex up-regulation of MT-1 mRNA levels. However, the repressive effects of Act D on
MT-1 gene expression gradually diminished with longer times of exposure to Dex. By 24 h, Dex treatment alone induced MT-1 gene expression by fivefold. As expected, Act $\mathrm{D}$ alone did not significantly affect STC mRNA abundance over the 24-h treatment period (Fig. 12C), but it abrogated the Dex-mediated reduction in STC gene expression when added simultaneously with Dex (Fig. 12D). An arrest in gene transcription was demonstrated by an $86 \%$ loss of MT-1 mRNA $24 \mathrm{~h}$ after addition of Act D in the presence or absence of Dex (Fig. 12C). In summary, these results showed that Dex could rapidly initiate the production of factor(s) that would increase the turnover of STC mRNA in AtT-20 cells and that these factor(s) were long-lived and functional even $24 \mathrm{~h}$ after cessation of gene transcription. The fact that the repressive action of Dex on STC mRNA appeared to be quicker and more potent than that observed for POMC mRNA, implied distinct repressive mechanisms.

\section{Discussion}

Since the discovery of mammalian STC expression in 1995 (Chang et al. 1995, 1996, Wagner et al. 1995, Olsen et al. 1996), various workers have proposed different roles for STC, primarily on the basis of correlative data and expression patterns (Sato et al. 1998, Zhang et al. 1998b, 2000, Iyer et al. 1999, Yoshiko et al. 1999, Jiang et al. 2000, Kahn et al. 2000). These studies provided some indication as to which regulatory pathways can induce STC production, but the specific factors responsible for the induction were not elucidated. Moreover, factors that can repress STC production have not been reported. To understand better the biology and function of STC in mammals, it is important to identify molecules capable of modulating its production and thereby provide a molecular basis for changes in STC production associated with specific physiological states. To this end, we chose the well-characterized mouse corticotrope tumor cell line, AtT-20, as an in vitro model to examine STC gene regulation by a variety of intercellular messengers. Unexpectedly, we found that glucocorticoids cause AtT-20 cells to undergo a rapid and significant reduction in steady-state STC mRNA levels that was accompanied by a distinct change in cell morphology. The glucocorticoid effect on STC mRNA was not restricted to AtT-20 cells, as similar results were evident in the human fibrosarcoma cell line, HT1080. Moreover, studies with the GR antagonist, RU-486, indicated that glucocorticoid-activated GR was responsible for controlling the abundance of STC mRNA. The fact that RU486 treatment counteracted the loss of STC mRNA in the presence of Dex implies that the underlying mechanism involves DNA binding and inhibition of transcription as expected for a type II nuclear receptor antagonist (Moguilewsky \& Philibert 1984, Gass et al. 1998, Zhang et al. 1998a). 
A

Dex

Treatment Co Dex $\rightarrow$ Act D

Time (h) $\quad \begin{array}{llllllll}0 & 240.5 & 1 & 2 & 5 & 8 & 24\end{array}$

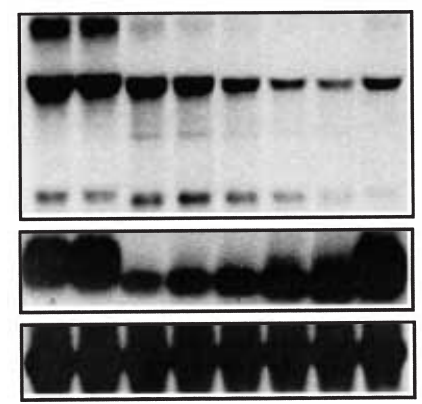

C

Time (h) $\quad \begin{array}{lllllll}0.5 & 1 & 2 & 5 & 8 & 24 & 24\end{array}$

Act D $\quad-++++++-$

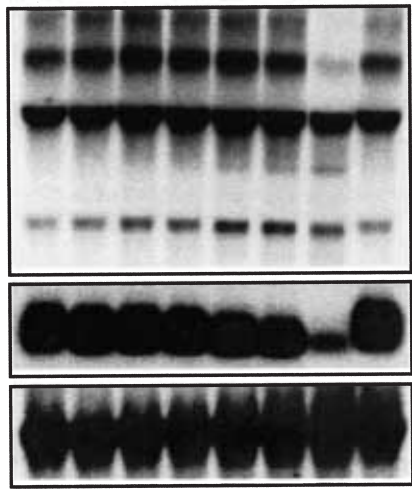

B

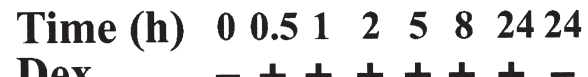

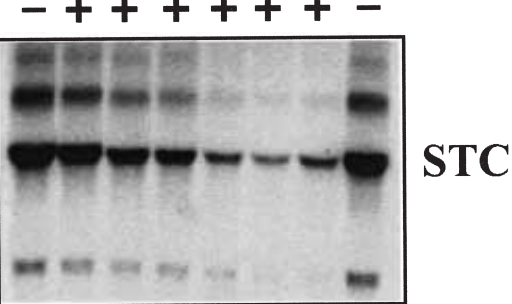

MT-1

$18 S$

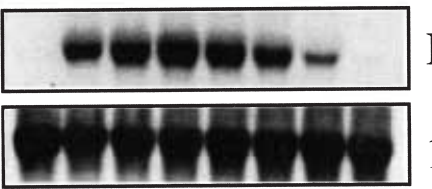

$18 S$

Dexras 1

$\mathbf{D}$

Time (h) $\quad 00.5122558242424$

Act D $\quad-++++++--$

STC

Dex
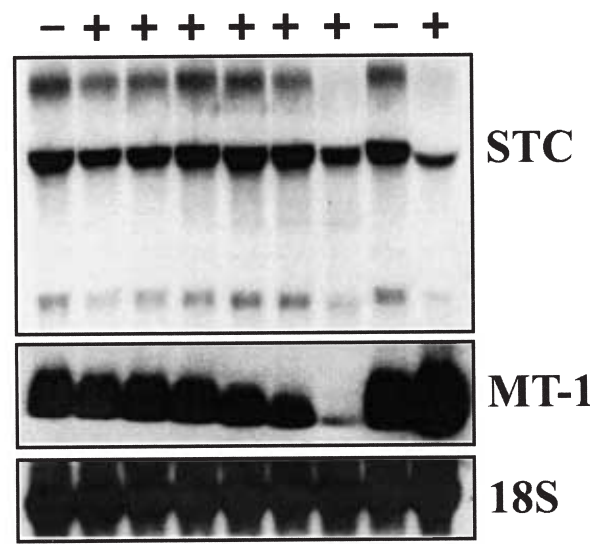

Figure 12 Steady-state STC mRNA levels in AtT-20 cells are down-regulated by Dex via induction of early gene(s). (A) AtT-20 cells were pretreated with $10^{-7} \mathrm{M}$ Dex for $0 \cdot 5,1,2,5$, and $8 \mathrm{~h}$, followed by Act D for another $24 \mathrm{~h}$. The right-hand $24-\mathrm{h}$ time point contains RNA from cells in Dex alone for the duration of the experiment. Lanes labeled 0 and 24 under Co refer to untreated, parallel, control AtT-20 cultures at 0 and $24 \mathrm{~h}$ time points of the experiment. Act D could not rescue Dex repression of STC mRNA levels after only a $2-\mathrm{h}$ pretreatment with Dex. AtT-20 cells cultured in OptiMEM/FCS were treated with $10^{-7} \mathrm{M}$ Dex (B), $10 \mu \mathrm{g} / \mathrm{ml} \mathrm{Act} \mathrm{D} \mathrm{(C),} \mathrm{or} \mathrm{with} 10^{-7} \mathrm{M}$ Dex and $10 \mu \mathrm{g} / \mathrm{ml}$ Act D together (D) for the indicated times. Comparison of the mRNA signals in panels (B), (C) and (D) indicates that Act D stabilized STC mRNA for at least $24 \mathrm{~h}$ in the presence of Dex, whereas MT-1 mRNA was gradually lost.

There are several molecular mechanisms by which activated GR represses gene expression. They focus almost exclusively on the presence of negative glucocorticoid response elements within a gene promoter (Drouin et al. 1993, Subramaniam et al. 1997, Malkoski \& Dorin 1999), and on trans-repression models in which GR interacts directly with other transcription factors to alter their activity (Meyer et al. 1997, De Bosscher et al. 2000). This is particularly relevant to the expression of POMC in
AtT-20 cells, in which a cis-active negative glucocorticoid response element was localized and shown to mediate transcriptional inhibition of $P O M C$ gene expression (Drouin et al. 1989). As expected, we found that Dex treatment of AtT-20 cells caused a reduction in POMC mRNA, but the time-course was much slower and the degree of inhibition much less than for STC mRNA. The GR also regulates gene expression post-transcriptionally, by either enhancing the stability of mRNAs (surfactant 
protein C (Boggaram \& Margana 1994) and fatty-acid synthase mRNAs (Xu \& Rooney 1997)) or increasing mRNA decay (somatostatin (Liu \& Patel 1995), cyclin D3 (Reisman \& Thompson 1995), and insulin mRNAs (Philippe \& Missotten 1990)). We examined the mechanism by which glucocorticoids down-regulated the steady-state level of STC mRNA in AtT-20 cells. The results from the nuclear run-on studies were not conclusive; however, transient transfection analysis with the STC proximal promoter suggested that glucocorticoid-mediated repression of STC is not at the transcriptional level. When AtT-20 cells were treated with the transcriptional inhibitor Act D, STC mRNA was protected from Dex-mediated repression. These results thus imply that glucocorticoids destabilize STC transcripts through de novo transcription of genes encoding proteins responsible for degrading STC mRNA.

In fish corpuscles of Stannius cells, $\mathrm{Ca}^{2+}$ is critically involved in up-regulating STC gene expression (Wagner 1994, Wagner \& Jaworski 1994). The stimulatory effect of $\mathrm{Ca}^{2+}$ on steady-state STC mRNA levels is due, in part, to a post-transcriptional regulatory process involving increased mRNA stabilization (Ellis \& Wagner 1995). The mechanism of fish STC mRNA stabilization is suggested to involve protein-mRNA interactions in the cytoplasm, whereby the polysomal complex protects mRNA from degradation. Thus post-transcriptional regulation of STC gene expression has been conserved from fish to mammalian cells but, in contrast to the findings in fish, we have demonstrated its susceptibility to negative regulation. Based on the fish STC data we also assessed the responsivity of the AtT-20 STC gene to increases in extracellular $\mathrm{Ca}^{2+}$ (data not shown), and did not detect changes in the steady-state level of STC mRNA. In addition, hypercalcemic culture conditions failed to overcome the Dexmediated repression of STC steady-state mRNA levels in AtT-20 cells. Consistent with these results, PKC stimulation by phorbol 12-myristate 13-acetate did not rescue STC gene expression when AtT-20 cells were grown in UltraMEM, indicating that intracellular $\mathrm{Ca}^{2+}$ mobilization could not rescue glucocorticoid inhibition of STC mRNA levels. These results are in contrast to those from a recent study that showed positive changes in steady-state STC mRNA levels by increasing extracellular $\mathrm{Ca}^{2+}$ in the culture media of MDCK cells, which are of kidney origin (Sheikh-Hamad et al. 2000). The fact that AtT-20 STC gene expression was not susceptible to $\mathrm{Ca}^{2+}$ regulation is not surprising, and implies that regulation by extracellular $\mathrm{Ca}^{2+}$ may require factors specific to renal cells.

The molecular basis for the control of mRNA degradation is not completely understood, and it is also not clear how glucocorticoids modulate this process. The mechanism for mRNA turnover is suggested to involve adenosine-uridine-rich sequences or polypyrimidine tracts located in the $3^{\prime}$-untranslated region (UTR) (Lagnado et al. 1994, Jacobson \& Peltz 1996). The embryonic lethal abnormal vision (ELAV)-like family of RNA-binding proteins is also implicated in regulating the stability of mRNAs for $\mathrm{p} 21$ (Joseph et al. 1998) and N-myc (Chagnovich et al. 1996). How glucocorticoids can specifically affect mRNA stability through cis-active mRNA sequences has not been elucidated; however, it has been reported that Dex can accelerate mRNA breakdown via $3^{\prime}$ UTR sequences of the surfactant protein-A and cyclooxygenase II mRNA (Hoover \& Floros 1999, Lasa et al. 2001). Moreover, glucocorticoids can alter the level of proteins that can bind to the $\beta_{2}$-adrenergic receptor message while also increasing the level of the $\beta_{2}$-receptor mRNA (Port et al. 1992).

We propose a model for glucocorticoid regulation of $S T C$ gene expression in which glucocorticoids induce the synthesis of protein(s) that, in turn, directly or indirectly interact with STC mRNA to decrease its stability. Given that our results regarding glucocorticoid regulation of STC were similar to those for cyclin D3, insulin and somatostatin mRNAs, it is possible that they constitute a class of mRNAs down-regulated by glucocorticoids through a common post-transcriptional mechanism. A recent study observed that glucocorticoid-induced repression of cyclin D3 gene expression involves two RNA-binding proteins that interact with two binding sites of 26 and 37 nucleotides, in the 3' UTR of cyclin D3 mRNA (Garcia-Gras et al. 2000). These proteins were reported to form a constitutive complex with cyclin D3 mRNA, which recruits an unknown protein induced by glucocorticoids, resulting in an unstable complex targeted for degradation. Whether this mechanism also applies to STC is not immediately apparent. However, alignment of nucleotide sequences in mouse cyclin D3 $3^{\prime}$ UTR with mouse STC $3^{\prime}$ UTR revealed that the 26-nucleotide binding site in cyclin D3 3' UTR had the greatest (68\%) identity with the sequence between 3263 and 3286 of STC 3' UTR. It remains to be determined whether this homologous nucleotide sequence in the STC $3^{\prime}$ UTR has a similar role in glucocorticoid-mediated destabilization of STC mRNA, as observed for cyclin D3 3' UTR. Alternatively, Dex-mediated destabilization of STC mRNA could occur at the $5^{\prime}$ end, as observed for rat monocyte chemoattractant protein 1 mRNA (Poon et al. 1999).

Our studies also found that the cAMP-signaling pathway, like general transcriptional inhibitors, antagonized the glucocorticoid-mediated down-regulation of STC mRNA. An increase in intracellular cAMP concentrations in AtT-20 cells induced STC gene expression when cells were cultured in UltraMEM. The results implied that STC gene expression was under the control of PKAmediated phosphorylation events. Although increased concentrations of cAMP did not globally repress transcription, it is entirely possible that cAMP inhibited the activity of glucocorticoid-induced protein(s) that destabilize STC mRNA. Increased cAMP could have de-repressed STC mRNA levels through PKA-mediated phosphorylation 
events at the transcriptional or post-transcriptional level. It could be argued that increased cAMP increased STC gene transcription, but the resultant mRNA would, presumably, have been subjected to Dex-mediated destabilization. Furthermore, subsequent experiments indicated that forskolin and CRF, in the absence of glucocorticoid, had no significant effect on steady-state STC mRNA levels (data not shown). Moreover, analysis of the MSTC promoter sequence did not reveal canonical cAMP response element binding protein sites through which cAMP could increase $S T C$ gene transcription. Alternatively, cAMP may activate transcription through other factors, such as the CCAAT/enhancer binding protein (Roesler 2000).

Interaction between the glucocorticoid and cAMPactivated signaling pathways has been documented at the transcriptional level and probably involves co-regulatory scaffolding proteins, such as cAMP binding protein (CBP) (Collingwood et al. 1999, Goldman et al. 1997). Glucocorticoids and cAMP generally function in a synergistic or additive manner at the transcriptional level (Liu et al. 1994, Pennie et al. 1995, Richardson et al. 1999), but examples of glucocorticoid antagonism of cAMP-activated transcription have also been reported for several genes, including corticotropin-releasing hormone (Guardiola-Diaz et al. 1996), $\alpha$-glycoprotein hormone subunit (Chatterjee et al. 1991), and arginase I (Morris et al. 1998). The mechanism by which these antagonistic effects occur has focused on events at the transcriptional level, with GR modulating the binding of transcription factors to the aforementioned gene promoters. To our knowledge, the results described here are the first demonstrating that activation of the cAMP-signaling pathway can alleviate glucocorticoidmediated inhibition of gene expression at the posttranscriptional level. cAMP has been demonstrated to alter the stability of a variety of mRNAs. The $\mathrm{Na}^{+} /$glucose cotransporter, SGLT1 (Lee et al. 2000) and lactate dehydrogenase A subunit (Tian et al. 1998) mRNAs are stabilized in the presence of cAMP-increasing agents, whereas type-1 plasminogen activator-inhibitor (Tillmann-Bogush et al. 1999, Heaton et al. 2000) and angiotensin receptor (Xu \& Murphy 2000) mRNAs are destabilized by cAMP analogues and cAMP-increasing agents. Therefore, it is likely that cAMP-mediated rescue of STC mRNA from glucocorticoid-induced turnover occurred at the post-transcriptional level, possibly through post-translational modification of RNA binding proteins specifically targetted to STC mRNA, as described for other genes (Tian et al. 1998, Lee et al. 2000).

In summary, our findings show for the first time that STC gene expression is susceptible to negative regulation, and provide an experimental paradigm with which to study the mechanism by which negative posttranscriptional regulation by glucocorticoids can be overcome by PKA-controlled factors. Further elucidation of this mechanism will be fundamental to our understanding of how glucocorticoids function and will also provide insights into how STC production can be modulated by glucocorticoids and the cAMP signaling pathway.

\section{Acknowledgements}

We are grateful to Mark Paciga and Kathy James for performing the STC RIA. Special thanks to Dr Joe Torchia for critical reading of the manuscript. This work was supported by a research-operating grant to G E D and G F W from the Canadian Institutes of Health Research.

\section{References}

Autelitano DJ, Lundblad JR, Blum M \& Roberts JL 1989 Hormonal regulation of POMC gene expression. Annual Review of Physiology $51715-726$.

Bilezikjian LM, Blount AL, Campen CA, Gonzalez-Manchon C \& Vale W 1991 Activin-A inhibits proopiomelanocortin messenger RNA accumulation and adrenocorticotropin secretion of AtT20 cells. Molecular Endocrinology 5 1389-1395.

Boggaram V \& Margana RK 1994 Developmental and hormonal regulation of surfactant protein $\mathrm{C}(\mathrm{SP}-\mathrm{C})$ gene expression in fetal lung. Role of transcription and mRNA stability. Journal of Biological Chemistry $26927767-27772$.

Butkus A, Roche PJ, Fernley RT, Haralambidis J, Penschow JD, Ryan GB, Trahair JF, Tregear GW \& Coghlan JP 1987 Purification and cloning of a corpuscles of Stannius protein from Anguilla australis. Molecular and Cellular Endocrinology 54 123-133.

Chagnovich D, Fayos BE \& Cohn SL 1996 Differential activity of ELAV-like RNA-binding proteins in human neuroblastoma. Journal of Biological Chemistry 271 33587-33591.

Chang AC, Janosi J, Hulsbeek M, de Jong D, Jeffrey KJ, Noble JR \& Reddel RR 1995 A novel human cDNA highly homologous to the fish hormone stanniocalcin. Molecular and Cellular Endocrinology 112 241-247.

Chang AC, Dunham MA, Jeffrey KJ \& Reddel RR 1996 Molecular cloning and characterization of mouse stanniocalcin cDNA. Molecular and Cellular Endocrinology 124 185-187.

Chatterjee VK, Madison LD, Mayo S \& Jameson JL 1991 Repression of the human glycoprotein hormone alpha-subunit gene by glucocorticoids: evidence for receptor interactions with limiting transcriptional activators. Molecular Endocrinology 5 100-110.

Collingwood TN, Urnov FD \& Wolffe AP 1999 Nuclear receptors: coactivators, corepressors and chromatin remodeling in the control of transcription. Journal of Molecular Endocrinology 23 255-275.

De Bosscher K, Vanden Berghe W \& Haegeman G 2000 Mechanisms of anti-inflammatory action and of immunosuppression by glucocorticoids: negative interference of activated glucocorticoid receptor with transcription factors. Journal of Neuroimmunology 109 $16-22$.

De Niu P, Olsen HS, Gentz R \& Wagner GF 1998 Immunolocalization of stanniocalcin in human kidney. Molecular and Cellular Endocrinology 137 155-159.

De Niu P, Radman DP, Jaworski EM, Deol H, Gentz R, Su J, Olsen HS \& Wagner GF 2000 Development of a human stanniocalcin radioimmunoassay: serum and tissue hormone levels and pharmacokinetics in the rat. Molecular and Cellular Endocrinology 162 131-144.

Drouin J, Trifiro MA, Plante RK, Nemer M, Eriksson P \& Wrange O 1989 Glucocorticoid receptor binding to a specific DNA sequence is required for hormone-dependent repression of pro-opiomelanocortin gene transcription. Molecular and Cellular Biology 9 5305-5314. 
Drouin J, Sun YL, Chamberland M, Gauthier Y, De Lean A, Nemer M \& Schmidt TJ 1993 Novel glucocorticoid receptor complex with DNA element of the hormone-repressed POMC gene. European Molecular Biology Organization Journal 12 145-156.

Ellis TJ \& Wagner GF 1995 Post-transcriptional regulation of the stanniocalcin gene by calcium. Journal of Biological Chemistry $\mathbf{2 7 0}$ 1960-1965.

Garcia-Gras EA, Chi P \& Thompson EA 2000 Glucocorticoidmediated destabilization of cyclin D3 mRNA involves RNA-protein interactions in the $3^{\prime}$-untranslated region of the mRNA. Journal of Biological Chemistry 275 22001-22008.

Gass EK, Leonhardt SA, Nordeen SK \& Edwards DP 1998 The antagonists RU486 and ZK98299 stimulate progesterone receptor binding to deoxyribonucleic acid in vitro and in vivo, but have distinct effects on receptor conformation. Endocrinology 139 1905-1919.

Goldman PS, Tran VK \& Goodman RH 1997 The multifunctional role of the co-activator $\mathrm{CBP}$ in transcriptional regulation. Recent Progress in Hormone Research 52 103-119.

Greenberg ME \& Bender TP 1997 Identification of newly transcribed RNA. In Current Protocols in Molecular Biology, vol 1, pp 4·10·1114-10·11. Eds FM Ausubel, R Brent, RE Kingston et al. Boston: John Wiley \& Sons, Inc.

Guardiola-Diaz HM, Kolinske JS, Gates LH \& Seasholtz AF 1996 Negative glucorticoid regulation of cyclic adenosine 3', $5^{\prime}$-monophosphate-stimulated corticotropin-releasing hormonereporter expression in AtT-20 cells. Molecular Endocrinology 10 317-329.

Heaton JH, Dlakic WM, Dlakic M \& Gelehrter TD 2000 Identification and cDNA cloning of a novel RNA-binding protein that interacts with the cyclic nucleotide responsive sequence in the type-1 plasminogen activator inhibitor mRNA. Journal of Biological Chemistry 22 3341-3347.

Honda S, Kashiwagi M, Ookata K, Tojo A \& Hirose S 1999 Regulation by 1 alpha,25-dihydroxyvitamin $\mathrm{D}(3)$ of expression of stanniocalcin messages in the rat kidney and ovary. FEBS Letters 459 119-122.

Hoover RR \& Floros J 1999 SP-A 3'-UTR is involved in the glucocorticoid inhibition of human SP-A gene expression. American Journal of Physiology 276 L917-L924.

Horiba N, Nicholson WE, Ch'ng JL \& Orth DN 1993 Chromogranin A does not mediate glucocorticoid inhibition of adrenocorticotropin secretion. Endocrinology 132 1585-1592.

Iyer VR, Eisen MB, Ross DT, Schuler G, Moore T, Lee JCF, Trent JM, Staudt LM, Hudson J Jr, Boguski MS, Lashkari D, Shalon D, Botstein D \& Brown PO 1999 The transcriptional program in the response of human fibroblasts to serum [see comments]. Science $\mathbf{2 8 3}$ 83-87.

Jacobson A \& Peltz SW 1996 Interrelationships of the pathways of mRNA decay and translation in eukaryotic cells. Annual Review of Biochemistry 65 693-739.

Jiang WQ, Chang AC, Satoh M, Furuichi Y, Tam PP \& Reddel RR 2000 The distribution of stanniocalcin 1 protein in fetal mouse tissues suggests a role in bone and muscle development. Journal of Endocrinology 165 457-466.

Joseph B, Orlian M \& Furneaux H 1998 p21(waf1) mRNA contains a conserved element in its $3^{\prime}$-untranslated region that is bound by the Elav-like mRNA-stabilizing proteins. Journal of Biological Chemistry 273 20511-20516.

Kahn J, Mehraban F, Ingle G, Xin X, Bryant JE, Vehar G, Schoenfeld J, Grimaldi CJ, Peale F, Draksharapu A, Lewin DA \& Gerritsen ME 2000 Gene expression profiling in an in vitro model of angiogenesis. American Journal of Pathology 156 1887-1900.

Kemppainen RJ \& Behrend EN 1998 Dexamethasone rapidly induces a novel ras superfamily member-related gene in AtT-20 cells. Journal of Biological Chemistry 273 3129-3131.
Knight RM, Farah JM, Bishop JF \& O’Donohue TL 1987 CRF and cAMP regulation of POMC gene expression in corticotrophic tumor cells. Peptides 8 927-934.

Lagnado CA, Brown CY \& Goodall GJ 1994 AUUUA is not sufficient to promote poly(A) shortening and degradation of an mRNA: the functional sequence within AU-rich elements may be UUAUUUA(U/A)(U/A). Molecular and Cellular Biology 14 7984-7995.

Lasa M, Brook M, Saklatvala J \& Clark AR 2001 Dexamethasone destabilizes cyclooxygenase 2 mRNA by inhibiting mitogenactivated protein kinase p38. Molecular and Cellular Biology 21 771-780.

Lee WY, Loflin P, Clancey CJ, Peng H \& Lever JE 2000 Cyclic nucleotide regulation of $\mathrm{Na}+$ /glucose cotransporter (SGLT1) mRNA stability. Interaction of a nucleocytoplasmic protein with a regulatory domain in the $3^{\prime}$-untranslated region critical for stabilization. Journal of Biological Chemistry 275 33998-34008.

Liu JL \& Patel YC 1995 Glucocorticoids inhibit somatostatin gene expression through accelerated degradation of somatostatin messenger ribonucleic acid in human thyroid medullary carcinoma (TT) cells. Endocrinology 136 2389-2396.

Liu JL, Papachristou DN \& Patel YC 1994 Glucocorticoids activate somatostatin gene transcription through co-operative interaction with the cyclic AMP signalling pathway. Biochemical Journal 301 863-869.

Lu M, Wagner GF \& Renfro JL 1994 Stanniocalcin stimulates phosphate reabsorption by flounder renal proximal tubule in primary culture. American Journal of Physiology 267 R1356-R1362.

Luini A, Lewis D, Guild S, Corda D \& Axelrod J 1985 Hormone secretagogues increase cytosolic calcium by increasing cAMP in corticotropin-secreting cells. PNAS 82 8034-8038.

Lundblad JR \& Roberts JL 1988 Regulation of proopiomelanocortin gene expression in pituitary. Endocrine Reviews 9 135-158.

Madsen KL, Tavernini MM, Yachimec C, Mendrick DL, Alfonso PJ, Buergin M, Olsen HS, Antonaccio MJ, Thomson AB \& Fedorak RN 1998 Stanniocalcin: a novel protein regulating calcium and phosphate transport across mammalian intestine. American Journal of Physiology 274 G96-G102.

Malkoski SP \& Dorin RI 1999 Composite glucocorticoid regulation at a functionally defined negative glucocorticoid response element of the human corticotropin-releasing hormone gene. Molecular Endocrinology 13 1629-1644.

Mayo KE \& Palmiter RD 1981 Glucocorticoid regulation of metallothionein-I mRNA synthesis in cultured mouse cells. Journal of Biological Chemistry 256 2621-2624.

Meyer T, Starr DB \& Carlstedt-Duke J 1997 The rat glucocorticoid receptor mutant K461A differentiates between two different mechanisms of transrepression. Journal of Biological Chemistry 272 21090-21095.

Moguilewsky M \& Philibert D 1984 RU 38486: potent antiglucocorticoid activity correlated with strong binding to the cytosolic glucocorticoid receptor followed by an impaired activation. Journal of Steroid Biochemistry 20 271-276.

Morris SM Jr, Kepka-Lenhart D \& Chen LC 1998 Differential regulation of arginases and inducible nitric oxide synthase in murine macrophage cells. American Journal of Physiology 275 E740-E747.

Olsen HS, Cepeda MA, Zhang QQ, Rosen CA, Vozzolo BL \& Wagner GF 1996 Human stanniocalcin: a possible hormonal regulator of mineral metabolism. PNAS 93 1792-1796.

Pennie WD, Hager GL \& Smith CL 1995 Nucleoprotein structure influences the response of the mouse mammary tumor virus promoter to activation of the cyclic AMP signalling pathway. Molecular and Cellular Biology 15 2125-2134.

Philippe J \& Missotten M 1990 Dexamethasone inhibits insulin biosynthesis by destabilizing insulin messenger ribonucleic acid in hamster insulinoma cells. Endocrinology 127 1640-1645. 
Poon M, Liu B \& Taubman MB 1999 Identification of a novel dexamethasone-sensitive RNA-destabilizing region on rat monocyte chemoattractant protein 1 mRNA. Molecular and Cellular Biology 19 6471-6478.

Port JD, Huang LY \& Malbon CC 1992 Beta-adrenergic agonists that down-regulate receptor mRNA up-regulate a $\mathrm{M}(\mathrm{r})$ 35,000 protein(s) that selectively binds to beta-adrenergic receptor mRNAs. Journal of Biological Chemistry 267 24103-24108.

Ragheb JA, Deen M \& Schwartz RH 1999 The destabilization of IL-2 mRNA by a premature stop codon and its differential stabilization by trans-acting inhibitors of protein synthesis do not support a role for active translation in mRNA stability. Journal of Immunology 163 3321-3330.

Reisine T, Rougon G, Barbet J \& Affolter HU 1985 Corticotropinreleasing factor-induced adrenocorticotropin hormone release and synthesis is blocked by incorporation of the inhibitor of cyclic AMP-dependent protein kinase into anterior pituitary tumor cells by liposomes. PNAS 82 8261-8265.

Reisman D \& Thompson EA 1995 Glucocorticoid regulation of cyclin D3 gene transcription and mRNA stability in lymphoid cells. Molecular Endocrinology 9 1500-1509.

Richardson J, Vinson C \& Bodwell J 1999 Cyclic adenosine-3',5'monophosphate-mediated activation of a glutamine synthetase composite glucocorticoid response element. Molecular Endocrinology 13 546-554

Roesler WJ 2000 What is a cAMP response unit? Molecular and Cellular Endocrinology 162 1-7.

Sato N, Kokame K, Shimokado K, Kato H \& Miyata T 1998 Changes of gene expression by lysophosphatidylcholine in vascular endothelial cells: 12 up-regulated distinct genes including 5 cell growth-related, 3 thrombosis-related, and 4 others. Journal of Biochemistry (Tokyo) 123 1119-1126.

Sheikh-Hamad D, Rouse D \& Yang Y 2000 Regulation of stanniocalcin in MDCK cells by hypertonicity and extracellular calcium. American Journal of Physiology and Renal Physiology 278 F417-F424.

Soloff MS, Jeng YJ, Copland JA, Strakova Z \& Hoare S 2000 Signal pathways mediating oxytocin stimulation of prostaglandin synthesis in select target cells. Experimental Physiology 85 51S-58S.

Stasko SE \& Wagner GF 2001 Stanniocalcin gene expression during mouse urogenital development: a possible role in mesenchymalepithelial signalling. Developmental Dynamics 220 49-59.

Subramaniam N, Cairns W \& Okret S 1997 Studies on the mechanism of glucocorticoid-mediated repression from a negative glucocorticoid response element from the bovine prolactin gene [published erratum appears in DNA]. Cell Biology 16 153-163.

Sundell K, Bjornsson BT, Itoh H \& Kawauchi H 1992 Chum salmon (Oncorhynchus keta) stanniocalcin inhibits in vitro intestinal calcium uptake in Atlantic cod (Gadus morhua). Journal of Comparative Physiology [B] 162 489-495.

Tang WJ \& Hurley JH 1998 Catalytic mechanism and regulation of mammalian adenylyl cyclases. Molecular Pharmacology 54 231-240.

Therrien M \& Drouin J 1993 Molecular determinants for cell specificity and glucocorticoid repression of the proopiomelanocortin gene. Annals of the New York Academy of Sciences $\mathbf{6 8 0} 663-671$.

Tian D, Huang D, Brown RC \& Jungmann RA 1998 Protein kinase A stimulates binding of multiple proteins to a U-rich domain in the $3^{\prime}$-untranslated region of lactate dehydrogenase A mRNA that is required for the regulation of mRNA stability. Journal of Biological Chemistry 273 28454-28460.

Tillmann-Bogush M, Heaton JH \& Gelehrter TD 1999 Cyclic nucleotide regulation of PAI-1 mRNA stability. Identification of cytosolic proteins that interact with an a-rich sequence. Journal of Biological Chemistry 274 1172-1179.

Varghese R, Wong CK, Deol H, Wagner GF \& DiMattia GE 1998 Comparative analysis of mammalian stanniocalcin genes.

Endocrinology 139 4714-4725.
Wagner GF 1994 The molecular biology of the corpuscles of stannius and regulation of stanniocalcin gene expression. In Fish Physiology, vol XIII, pp 273-306. Eds N Sherwood \& C Hew. New York: Academic Press, Inc.

Wagner GF \& Jaworski E 1994 Calcium regulates stanniocalcin mRNA levels in primary cultured rainbow trout corpuscles of Stannius. Molecular and Cellular Endocrinology 99 315-322.

Wagner GF, Hampong M, Park CM \& Copp DH 1986 Purification, characterization, and bioassay of teleocalcin, a glycoprotein from salmon corpuscles of Stannius. General and Comparative Endocrinology 63 481-491.

Wagner GF, Fenwick JC, Park CM, Milliken C, Copp DH \& Friesen HG 1988 Comparative biochemistry and physiology of teleocalcin from sockeye and coho salmon. General and Comparative Endocrinology 72 237-246.

Wagner GF, Gellersen B \& Friesen HG 1989 Primary culture of teleocalcin cells from rainbow trout corpuscles of Stannius: regulation of teleocalcin secretion by calcium. Molecular and Cellular Endocrinology 62 31-39.

Wagner GF, Milliken C, Friesen HG \& Copp DH 1991 Studies on the regulation and characterization of plasma stanniocalcin in rainbow trout. Molecular and Cellular Endocrinology 79 129-138.

Wagner GF, Guiraudon CC, Milliken C \& Copp DH 1995 Immunological and biological evidence for a stanniocalcin-like hormone in human kidney. PNAS 92 1871-1875.

Wagner GF, Vozzolo BL, Jaworski E, Haddad M, Kline RL, Olsen HS, Rosen CA, Davidson MB \& Renfro JL 1997 Human stanniocalcin inhibits renal phosphate excretion in the rat. Journal of Bone Mineral Research 12 165-171.

Wang L, Yang H \& Adamo ML 2000 Glucose starvation reduces IGF-I mRNA in tumor cells: evidence for an effect on mRNA stability. Biochemical and Biophysical Research Communications 269 336-346.

van Wijk PA, van Neck JW, Rijnberk A, Croughs RJ \& Mol JA 1995 Proliferation of the murine corticotropic tumour cell line AtT20 is affected by hypophysiotrophic hormones, growth factors and glucocorticoids. Molecular and Cellular Endocrinology 111 13-19.

Xu K \& Murphy TJ 2000 Reconstitution of angiotensin receptor mRNA down-regulation in vascular smooth muscle. Posttranscriptional control by protein kinase A but not mitogenic signaling directed by the $5^{\prime}$-untranslated region. Journal of Biological Chemistry 275 7604-7611.

Xu ZX \& Rooney SA 1997 Glucocorticoids increase fatty-acid synthase mRNA stability in fetal rat lung. American Journal of Physiology 272 L860-L864.

Yoon DY, Ma Y, Krikun G, Lockwood CJ, LaChapelle L \& Guller S 1998 Glucocorticoid effects in the human placenta: evidence that dexamethasone-mediated inhibition of fibronectin expression in cytotrophoblasts involves a protein intermediate. Journal of Clinical Endocrinology and Metabolism 83 632-637.

Yoshiko Y, Son A, Maeda S, Igarashi A, Takano S, Hu J \& Maeda N 1999 Evidence for stanniocalcin gene expression in mammalian bone. Endocrinology 140 1869-1874.

Zhang X, Jeyakumar M, Petukhov S \& Bagchi MK 1998a A nuclear receptor corepressor modulates transcriptional activity of antagonistoccupied steroid hormone receptor. Molecular Endocrinology $\mathbf{1 2}$ 513-524.

Zhang KZ, Westberg JA, Paetau A, von Boguslawsky K, Lindsberg P, Erlander M, Guo H, Su J, Olsen HS \& Andersson LC 1998b High expression of stanniocalcin in differentiated brain neurons. American Journal of Pathology 153 439-445.

Zhang K, Lindsberg PJ, Tatlisumak T, Kaste M, Olsen HS \& Andersson LC 2000 Stanniocalcin: a molecular guard of neurons during cerebral ischemia. PNAS 97 3637-3642.

Received 19 May 2001

Accepted 21 August 2001 